USDA Foreign Agricultural Service

Global Agricultural Information Network

THIS REPORT CONTAINS ASSESSMENTS OF COMMODITY AND TRADE ISSUES MADE BY USDA STAFF AND NOT NECESSARILY STATEMENTS OF OFFICIAL U.S. GOVERNMENT POLICY

Required Report - public distribution

Date: $4 / 1 / 2016$

GAIN Report Number: AU1603

\title{
EU-28
}

\section{Oilseeds and Products Annual}

\section{6}

\section{Approved By:}

Kelly Stange

\section{Prepared By:}

Roswitha Krautgartner, Lucile Lefebvre, Leif Erik Rehder, Mila

Boshnakova, Monica Dobrescu, Bob Flach, Jennifer Wilson,

Dimosthenis Faniadis, Marta Guerrero, Barrie Williams, and the

group of FAS oilseeds specialists in the EU

\section{Report Highlights:}

Total European Union oilseeds area in MY 2016/17 is forecast to increase by about 1.6 percent to almost 12 million hectares. The increase is explained by increasing area of all three major oilseeds rapeseed, sunflower and soybeans. The higher acreage, in combination with expectations of more average yields compared to the low yields of sunflower and rapeseed due to drought in MY 2015/16, leads to a forecast of 33.4 MMT for total oilseeds. As of March 2016, planting and growing conditions for oilseeds have been very good in general. Total EU-28 oilseeds meal consumption in MY 2016/17 is estimated to be up by 0.4 percent year-on-year reaching 54.1 MMT. The growing EU poultry sector is influential in driving higher demand for protein feed. 


\section{Executive Summary:}

Coordinator: Roswitha Krautgartner, FAS/Vienna

\section{Production}

Total European Union (EU) oilseeds area in MY (marketing year) 2016/17 is forecast to increase by about 1.6 percent to almost 12 million hectares (ha). The increase is explained by increasing area of all three major oilseeds - rapeseed, sunflower and soybeans. The higher acreage, in combination with more average yields expectations compared to the low yields of particularly sunflower and rapeseed due to drought in MY 2015/16, leads to a forecast of 33.4 MMT (million metric tons) which compares to an increase of 3.4 percent. As of March 2016, planting and growing conditions for oilseeds have been very good in general, but weather conditions in April and May will be crucial for spring plantings and the yields and quality of the rapeseed crop. The EU is the world's largest producer of rapeseed and rapeseed remains the most important oilseed crop produced in the EU. In MY 2016/17, the forecast for planted area of EU rapeseed is 2 percent higher and reaching 6.6 million ha compared to the previous year. The higher acreage is mainly due to increases in Romania, Lithuania, Latvia and the Czech Republic and to a lesser extent in Estonia and Denmark. Increased rapeseed area in the Baltic countries is driven by the demand for the biofuels industry. Following a decline in area and yields per hectare due to drought in MY 2015/16, sunflower plantings and yields are expected to grow again in MY 2016/17. Sunflower area is expected to grow by 1.7 percent and reach 4.25 million ha with a forecasted crop totaling at 8.35 MMT (plus 9.2 percent). Growth is expected in the major producing countries Spain, Romania and Bulgaria, which will exceed slight declines in France, Hungary and especially Italy. Increased sunflower plantings are motivated by better profit margins, resilience to heat and drought, more favorable crush margins and the opportunity for premiums on specialty types of sunflower such as high oleic, linoleic and confectionary sunflower. Areas for specialty sunflower types are reported to grow in France, Romania and Bulgaria. Still at a relatively low level production, soybean keeps increasing in MY 2016/17 but at a slower pace than in MY 2015/16. The drivers for the growth in European soybean production are EU policy incentives. Rising area is expected in France, Romania, Hungary, Austria, Slovakia and the Czech Republic, while a decline in Italy and Bulgaria is expected. Total soybean area for MY 2016/17 is forecast at 835 thousand ha (plus 4.8 percent year-on-year) with a total production of 2.25 MMT increasing by 2.7 percent compared to the previous MY. Despite increased production of EU oilseeds EU total crush is expected to be somewhat down in MY 2016/17 by 0.14 percent. Only sunflower crush is forecast to increase due to increased supply and improved crush margins for sunflower. Increased sunflower crush is more than offset by lower soybean and rapeseed crush.

\section{Consumption and Trade}

The EU is highly dependent on imports of oilseeds and oilseeds products (protein meals and vegetable oils) to meet demand for food, feed and industrial uses, including biofuels production. This is especially true for oilseeds with no or limited domestic production, such as soybeans, soybean products and palm oil. Some 65 percent of soybean meal and almost 50 percent of sunflower meal must be imported. Only the production of rapeseed meal is on an average equal or somewhat higher than the domestic demand. Total EU oilseeds meal consumption in MY 2016/17 is estimated to be up by 0.4 percent year-on-year reaching 54.1 MMT. Particularly the growing EU poultry sector is driving higher demand for protein feed. Ample world supplies of soybeans and soybean meal are expected to favor the use of soybean products in MY 2016/17 at the expense of rapeseed meal. Use of sunflower meal is expected to also increase due to higher domestic supply. Total use of vegetable oils is forecast to decrease by about 0.8 percent to $25.0 \mathrm{MMT}$ which is mainly due to decreased industrial use but increasing food use. The production of biofuels is the second largest use of vegetable oils after food use in the EU. Since more and more vegetable oils are being replaced by waste fats and oils, the use of vegetable oils for biofuels production is declining. Most EU biodiesel production uses rapeseed oil as the main feedstock. 


\section{Policy}

The "greening component" in Pillar 1 of the new CAP (Common Agriculture Policy) includes three elements of greening that all farmers would have to comply with to receive direct payments. The three components are: crop diversification; conservation of permanent grassland; and the ecological focus areas (EFA). One option for EFAs is to have nitrogen-fixing crops, e.g. protein crops.

In the new CAP, the Commission gives MS the opportunity to support the production of protein crops with up to two percent of their national envelopes. Should any MS decide to use this possibility, the Commission has to be notified in advance. MS must have notified the Commission by August 2014 to benefit from this option from January 1,2015 . Similarly, if the MS wanted to use the coupled option from January 1,2016 , the Commission must have notified by August 2015.

The use of three neonicotinoids (clothianidin, imidacloprid and thiametoxam) has been restricted since December 1, 2013 for a period of two years on crops attractive to honeybees such as rapeseed, sunflowers, and soybeans.

\section{Introduction}

This report presents the outlook for oilseeds in the EU-28. The data in this report is based on the views of Foreign Agricultural Service (FAS) analysts in the EU and is not official USDA data.

This report was a group effort of the following FAS analysts:

Ornella Bettini

Mila Boshnakova

Monica Dobrescu

Bob Flach

Dimosthenis Faniadis

Gellert Golya

Marta Guerrero

Roswitha Krautgartner

Lucile Lefebvre

Jana Mikulasova

Andreja Misir

Yvan Polet

Leif Erik Rehder

Piotr Rucinski

Barrie Williams

Jennifer Wilson
FAS/Rome covering Italy

FAS/Sofia covering Bulgaria

FAS/Bucharest covering Romania

FAS/The Hague covering The Netherlands, Sweden, Finland, and Denmark

FAS/Rome covering Greece

FAS/Budapest covering Hungary

FAS/Madrid covering Spain and Portugal

FAS/Vienna covering Austria and Slovenia

FAS/Paris covering France

FAS/Prague covering the Czech Republic and Slovakia

FAS/Zagreb covering Croatia

FAS/USEU Brussels covering Belgium and Luxembourg

FAS/Berlin covering Germany

FAS/Warsaw covering Poland, Estonia, Latvia, and Lithuania

FAS/USEU Brussels

FAS/London covering the U.K. and Ireland

The FAS EU-28 oilseeds reporting team would like to thank Agata Kingsbury from FAS/OGA for her valuable input and support. 


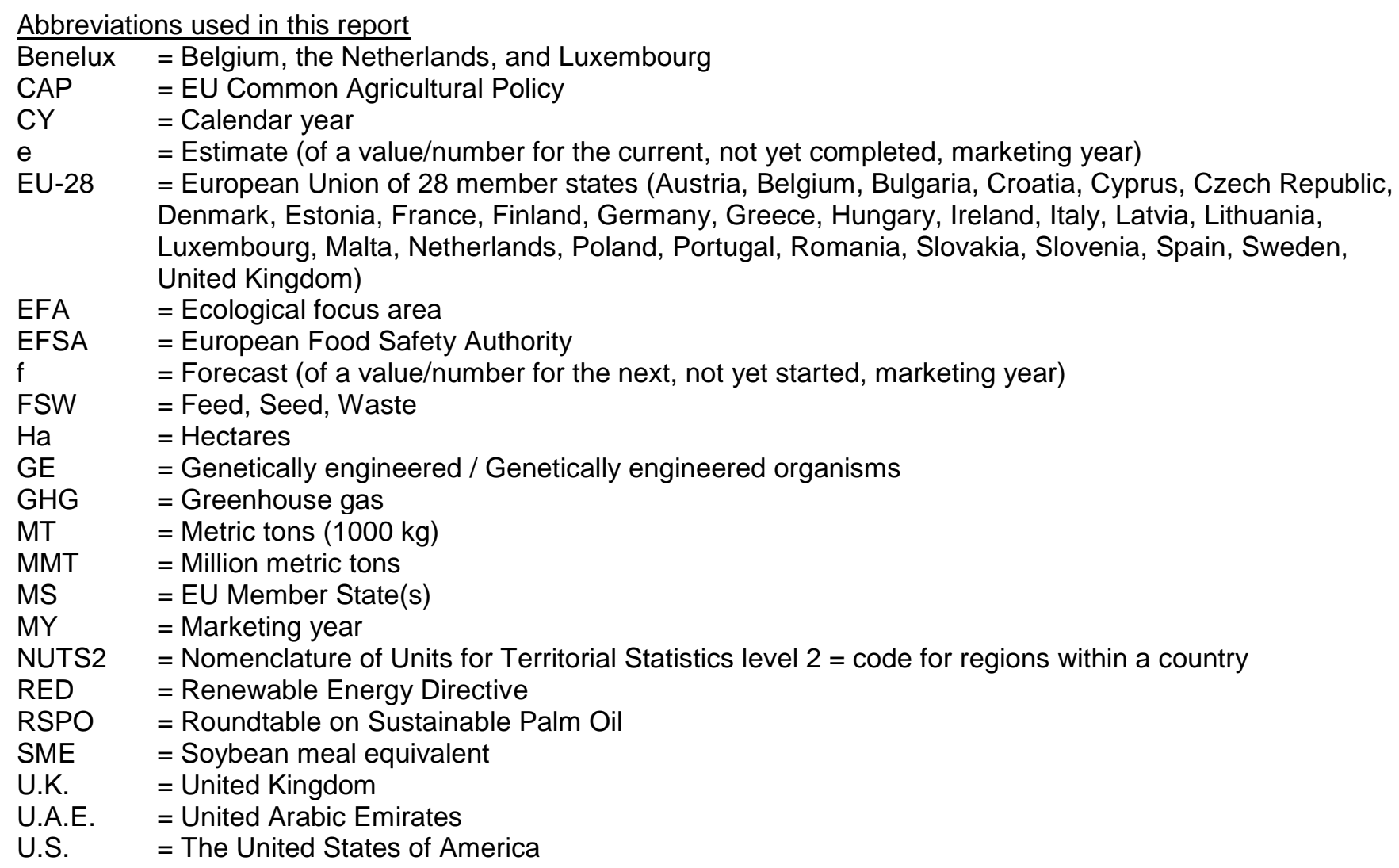

In this report "biofuel" includes only biofuels used in the transport sector. Biomass/biofuel used for electricity production or other technical uses such as lubricants or in detergents are included in "industrial use".

The marketing years used in this report are:

\author{
January - December \\ Copra complex \\ Palm Kernel complex \\ Palm Oil \\ Fish Meal \\ July - June \\ Rapeseed complex \\ October - September \\ Soybean complex \\ Sunflower complex \\ Cottonseed complex \\ Peanut complex \\ November - October \\ Olive Oil
}

\title{
$\underline{\text { Table of Contents }}$
}


1. Total Oilseeds

2. Soybean Complex

3. Rapeseed Complex

4. Sunflower Complex

5. Palm Kernel Complex

6. Palm Oil

7. Peanut Complex

8. Fish Meal

9. Copra Complex

10. Cotton Seed Complex

11. Olive Oil

12. Policy

13. Oilseeds GAIN Reports

14. Related GAIN Reports

\section{Total Oilseeds}

Coordinator: Roswitha Krautgartner, FAS/Vienna

Note: Total oilseeds include different marketing years with different beginning and ending months. Details for the specific commodities please find in the respective sections.

\section{Total Oilseeds - Seeds}

\begin{tabular}{|c|c|c|c|c|c|c|}
\hline \multirow{3}{*}{\begin{tabular}{|l|} 
Commodity: \\
Marketing Year \\
\end{tabular}} & \multicolumn{6}{|c|}{ Total Oilseeds } \\
\hline & \multicolumn{2}{|c|}{ MY 2014/15 } & \multicolumn{2}{|c|}{ MY 2015/16 } & \multicolumn{2}{|c|}{ MY 2016/17 } \\
\hline & USDA Official & Post New & USDA Official & Post New & USDA Official & Post New \\
\hline Area & 11,962 & 11,962 & 11,771 & 11,778 & & 11,970 \\
\hline Beginning Stocks & 3,413 & 3,413 & 3,353 & 3,499 & & 2,444 \\
\hline Production & 35,715 & 35,859 & 31,983 & 32,318 & & 33,402 \\
\hline Extra EU27 imports & 16,797 & 16,805 & 17,085 & 17,125 & & 16,495 \\
\hline TOTAL SUPPLY & 55,925 & 56,077 & 52,421 & 52,942 & & 52,341 \\
\hline Extra EU27 exports & 1,299 & 1,296 & 925 & 880 & & 980 \\
\hline Crush & 47,512 & 46,914 & 46,012 & 45,266 & & 45,201 \\
\hline Food Use & 1,468 & 1,458 & 1,455 & 1,469 & & 1,472 \\
\hline Feed, Seed, Waste & 2,293 & 2,910 & 2,203 & 2,883 & & 2,931 \\
\hline TOTAL DOMESTIC USE & 51,273 & 51,282 & 49,670 & 49,618 & & 49,604 \\
\hline Ending Stocks & 3,353 & 3,499 & 1,826 & 2,444 & & 1,757 \\
\hline TOTAL DISTRIBUTION & 55,925 & 56,077 & 52,421 & 52,942 & & 52,341 \\
\hline
\end{tabular}

Please note that numbers for total oilseeds seeds include cottonseed which is not included in oilseeds meals and oils.

Source: FAS EU-28

\section{EU-28 Total Oilseeds Area}

\section{MY 2016/17}

Total EU-28 oilseeds area in MY 2016/17 is forecast to increase by about 1.6 percent compared to the previous year and is expected to reach almost 12 million ha. The increase is explained by increasing acreage of all three major oilseeds - rapeseed, sunflower and soybeans. 


\section{MY 2015/16}

In MY 2014/15, total EU-28 oilseeds area is down by 1.5 percent, due to a lower rapeseed and sunflower area which is partially offset by increased soybean area.

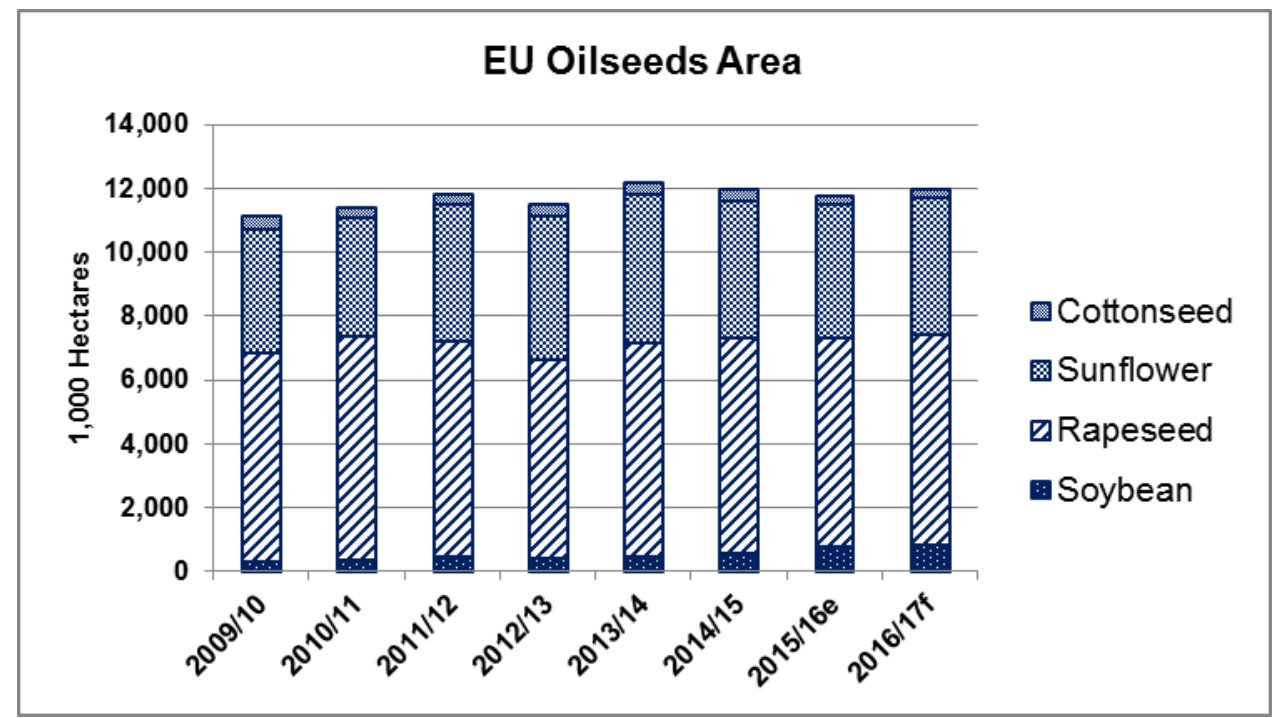

\section{Source: FAS EU-28}

\section{EU-28 Total Oilseeds Production}

\section{MY 2016/17}

Expectations for total EU-28 oilseeds production in MY 2016/17 are for a 3.4 percent increase to 33.4 MMT. To a majority this is the result of more average yields in sunflower crop compared to the low result in the previous dry season and increased acreage.

\section{MY 2015/16}

Drought in MY 2015/16 lowered yields particularly in sunflower crop. Together with lower acreage of rapeseed and sunflower total oilseeds production was year-on-year down by almost 10 percent.

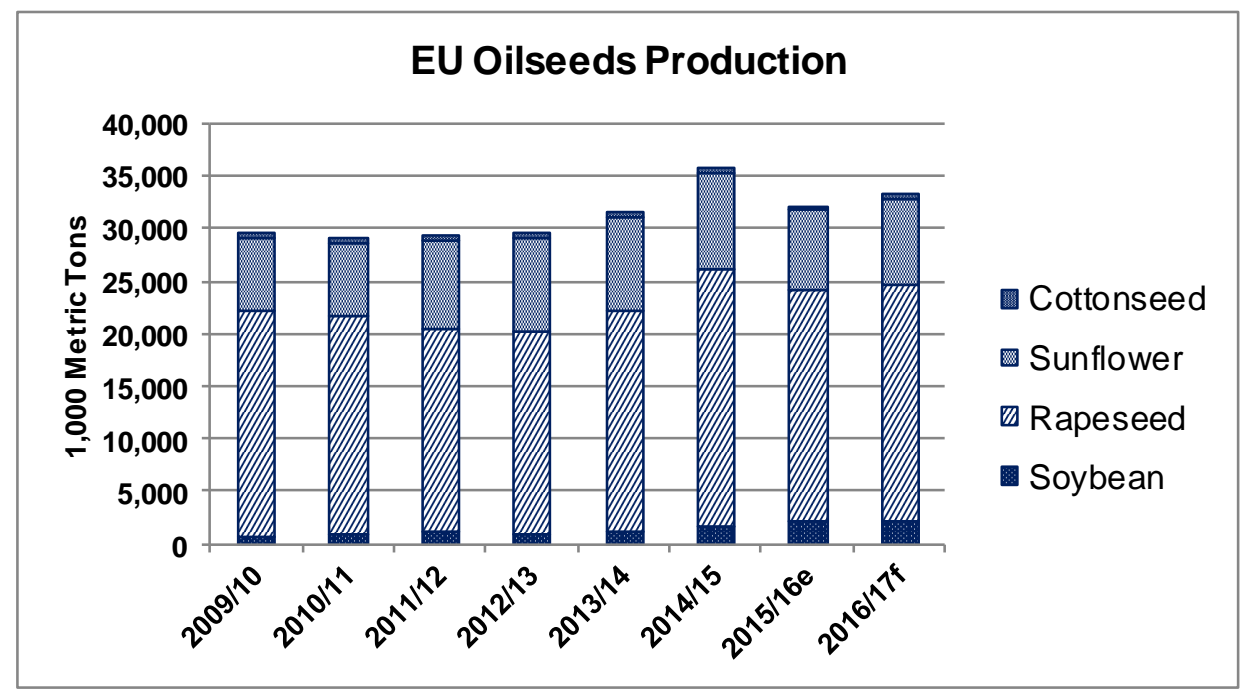

Source: FAS EU-28 


\section{EU-28 Total Oilseeds Crush}

\section{MY 2016/17}

Despite higher production total EU-28 oilseeds, crush is expected to slightly decline by 0.1 percent to 45.2 MMT. This is a result of decreased rapeseed and soybean crush but increased sunflower crush.

\section{MY 2015/16}

Due to lower total production but increased imports of rapeseed, total EU-28 oilseeds crush is estimated to decrease by only 3.5 percent and reach 45.3 MMT.

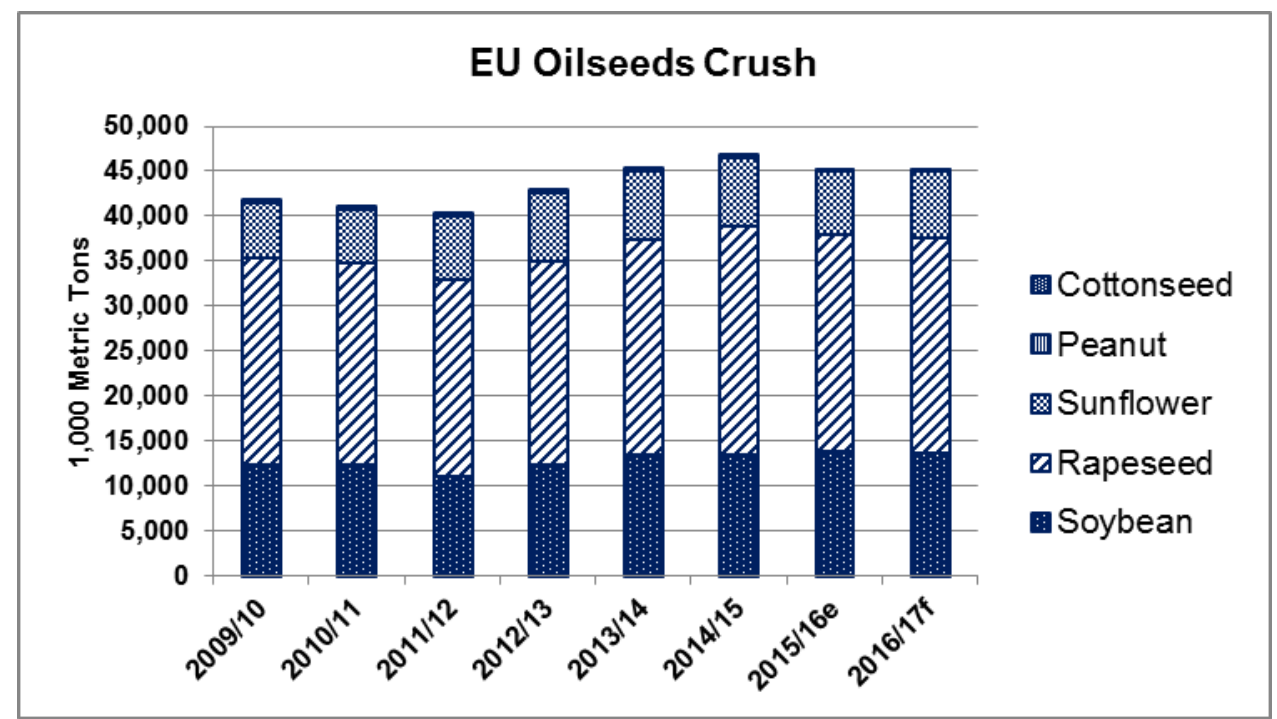

Note: Crush for olive oil production is not included.

Source: FAS EU-28

Total Oilseeds - Meals

\begin{tabular}{|c|c|c|c|c|c|c|}
\hline \multirow{3}{*}{$\begin{array}{l}\text { Commodity } \\
\text { Marketing Year }\end{array}$} & \multicolumn{6}{|c|}{ Total Meals } \\
\hline & \multicolumn{2}{|c|}{ MY 2014/15 } & \multicolumn{2}{|c|}{ MY 2015/16 } & \multicolumn{2}{|c|}{ MY 2016/17 } \\
\hline & USDA Official & Post New & USDA Official & Post New & USDA Official & Post New \\
\hline Crush & 47,183 & 46,585 & 45,732 & 44,985 & & 44,935 \\
\hline Beginning Stocks & 654 & 654 & 579 & 815 & & 801 \\
\hline Production & 30,392 & 29,629 & 29,465 & 28,783 & & 28,715 \\
\hline Extra EU27 imports & 25,391 & 25,392 & 26,960 & 26,327 & & 26,457 \\
\hline TOTAL SUPPLY & 56,437 & 55,675 & 57,004 & 55,925 & & 55,973 \\
\hline Extra EU27 exports & 1,283 & 1,283 & 1,175 & 1,210 & & 1,140 \\
\hline Industrial & 510 & 510 & 510 & 510 & & 510 \\
\hline Food Use & 32 & 32 & 32 & 32 & & 32 \\
\hline Feed, Seed, Waste & 54,033 & 53,035 & 54,859 & 53,372 & & 53,572 \\
\hline TOTAL DOMESTIC USE & 54,575 & 53,577 & 55,401 & 53,914 & & 54,114 \\
\hline Ending Stocks & 579 & 815 & 428 & 801 & & 719 \\
\hline TOTAL DISTRIBUTION & 56,437 & 55,675 & 57,004 & 55,925 & & 55,973 \\
\hline $000 \mathrm{MT}$ & & & & & & \\
\hline
\end{tabular}

Please note that numbers in oilseeds meals and oils do not include cottonseeds as cottonseed meal and cottonseed oil are not included in this report.

Source: FAS EU-28 


\section{MY 2016/17}

In line with the somewhat lower crush in MY 2016/17, EU-28 total oilseeds meal production is expected to decline by 0.2 percent to $28.7 \mathrm{MMT}$. Total supply of oilseed meals is forecast to remain almost flat due to slightly increased imports making up for the decline in production. A growing poultry sector leads to expectations of increased soybean meal use for feed. Increased feed use of sunflower meal is expected to make up for lower feed use of rapeseed meal. As a consequence total feed use of oilseeds meals is forecast to slightly increase totaling 53.6 MMT.

\section{MY 2015/16}

Increased demand in the animal sector and sufficient supply of soybean meal on the world market leads to increased feed use of soybean meal at the expense of rapeseed and sunflower meal. Driven by the growing animal sector, total feed use of oilseeds meals is expected to grow.

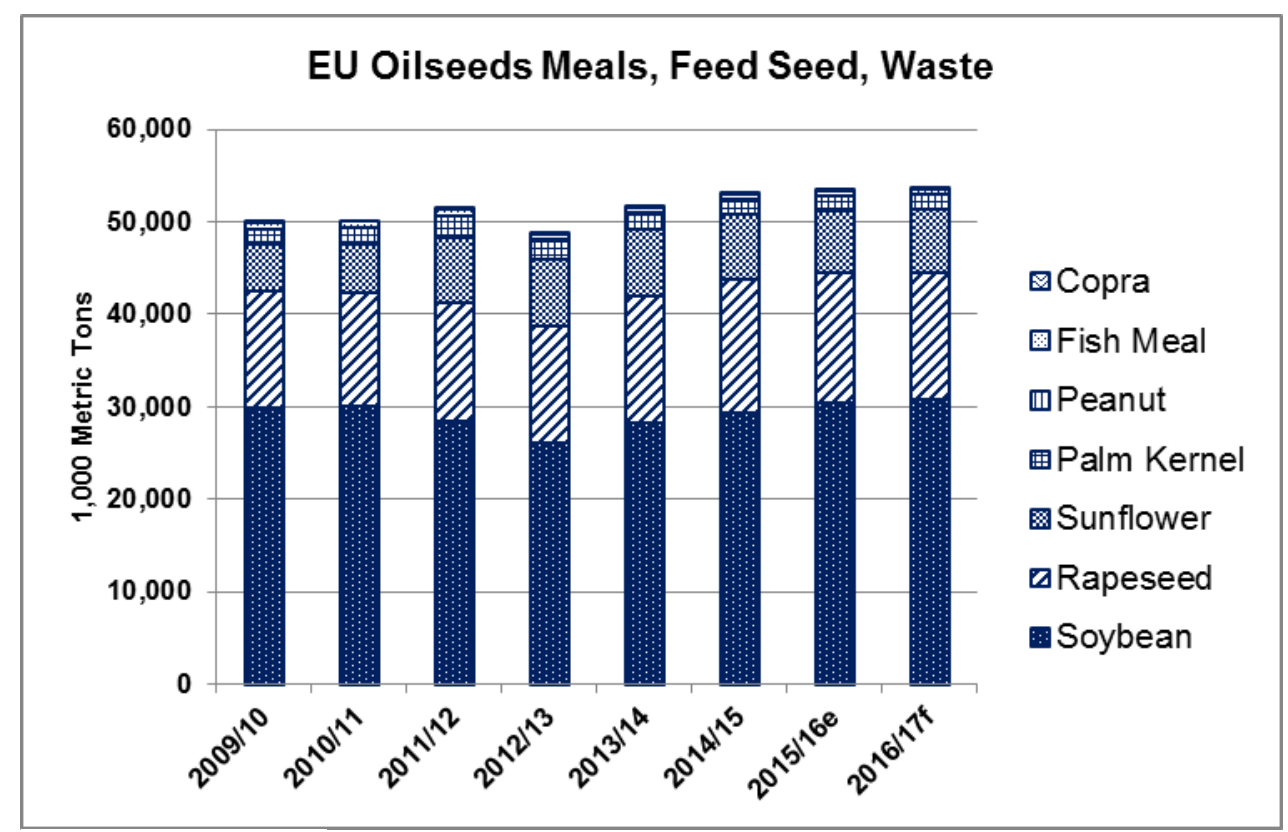

\section{Source: FAS EU-28}

Feed Use of EU-28 Total Oilseeds in Soymeal Equivalents (SME) in 1000 MT

\begin{tabular}{|l|c|r|r|r|r|r|r|r|}
\hline $\begin{array}{l}\text { Feed Seed } \\
\text { Waste }\end{array}$ & $\begin{array}{c}2009 / 1 \\
\text { SME Meals }\end{array}$ & $\begin{array}{c}2010 / 1 \\
1\end{array}$ & $\begin{array}{c}2011 / 1 \\
2\end{array}$ & $\begin{array}{c}2012 / 1 \\
3\end{array}$ & $\begin{array}{c}2013 / 1 \\
4\end{array}$ & $\begin{array}{c}2014 / 1 \\
5\end{array}$ & $\begin{array}{c}2015 / 16 \\
\mathrm{e}\end{array}$ & $\begin{array}{c}2016 / 17 \\
f\end{array}$ \\
\hline Soybean & 29,861 & 29,987 & 28,431 & 26,000 & 28,300 & 29,300 & 30,500 & 30,700 \\
\hline Rapeseed & 8,936 & 8,815 & 9,072 & 9,072 & 9,676 & 10,246 & 9,890 & 9,819 \\
\hline Sunflower & 4,815 & 4,950 & 6,751 & 6,794 & 6,798 & 6,704 & 6,421 & 6,515 \\
\hline $\begin{array}{l}\text { Palm } \\
\text { Kernel }\end{array}$ & 594 & 622 & 795 & 764 & 629 & 599 & 569 & 569 \\
\hline Peanut & 66 & 79 & 43 & 29 & 30 & 21 & 21 & 21 \\
\hline Fish Meal & 957 & 1,019 & 972 & 796 & 861 & 764 & 795 & 795 \\
\hline Copra & 15 & 0 & 7 & 5 & 1 & 1 & & 1 \\
\hline Total & 45,245 & 45,473 & 46,070 & 43,460 & 46,296 & 47,636 & 48,197 & 48,420 \\
\hline
\end{tabular}

Source: FAS EU-28 
Total Oilseeds - Oils

\begin{tabular}{|c|c|c|c|c|c|c|}
\hline \multirow{3}{*}{$\begin{array}{l}\text { Commodity: } \\
\text { Marketing Year }\end{array}$} & \multicolumn{6}{|c|}{ Total Oils } \\
\hline & \multicolumn{2}{|c|}{ MY 2014/15 } & \multicolumn{2}{|c|}{ MY 2015/16 } & \multicolumn{2}{|c|}{ MY 2016/17 } \\
\hline & USDA Official & Post New & USDA Official & Post New & USDA Official & Post New \\
\hline Beginning Stocks & 1,850 & 1,850 & 1,451 & 1,308 & & 1,179 \\
\hline Production & 17,967 & 17,770 & 17,894 & 17,637 & & 17,720 \\
\hline Extra EU27 imports & 9,592 & 9,573 & 9,685 & 9,665 & & 9,543 \\
\hline TOTAL SUPPLY & 29,409 & 29,193 & 29,030 & 28,610 & & 28,452 \\
\hline Extra EU27 exports & 2,482 & 2,408 & 2,426 & 2,245 & & 2,260 \\
\hline Industrial & 12,270 & 3,370 & 12,090 & 3,390 & & 3,340 \\
\hline Biofuels & 0 & 8,790 & 0 & 8,530 & & 8,380 \\
\hline Food Use & 12,851 & 12,885 & 13,109 & 12,854 & & 12,862 \\
\hline Feed, Seed, Waste & 355 & 432 & 355 & 412 & & 412 \\
\hline TOTAL DOMESTIC USE & 25,476 & 25,377 & 25,554 & 25,186 & & 24,994 \\
\hline Ending Stocks & 1,451 & 1,308 & 1,058 & 1,179 & & 1,188 \\
\hline TOTAL DISTRIBUTION & 29,409 & 29,193 & 29,030 & 28,610 & & 28,452 \\
\hline
\end{tabular}

Please note that numbers in oilseeds meals and oils do not include cottonseeds as cottonseed meal and cottonseed oil is not included in this report.

Source: FAS EU-28

\section{MY 2016/17}

In line with the somewhat lower crush in MY 2016/17, EU-28 total oilseeds oil production is expected to decline by 0.5 percent to $17.7 \mathrm{MMT}$. With slightly increased food use but decreasing industrial and biofuels use, total consumption of oilseeds oils is expected to decline by 0.8 percent and reach $28.5 \mathrm{MMT}$.

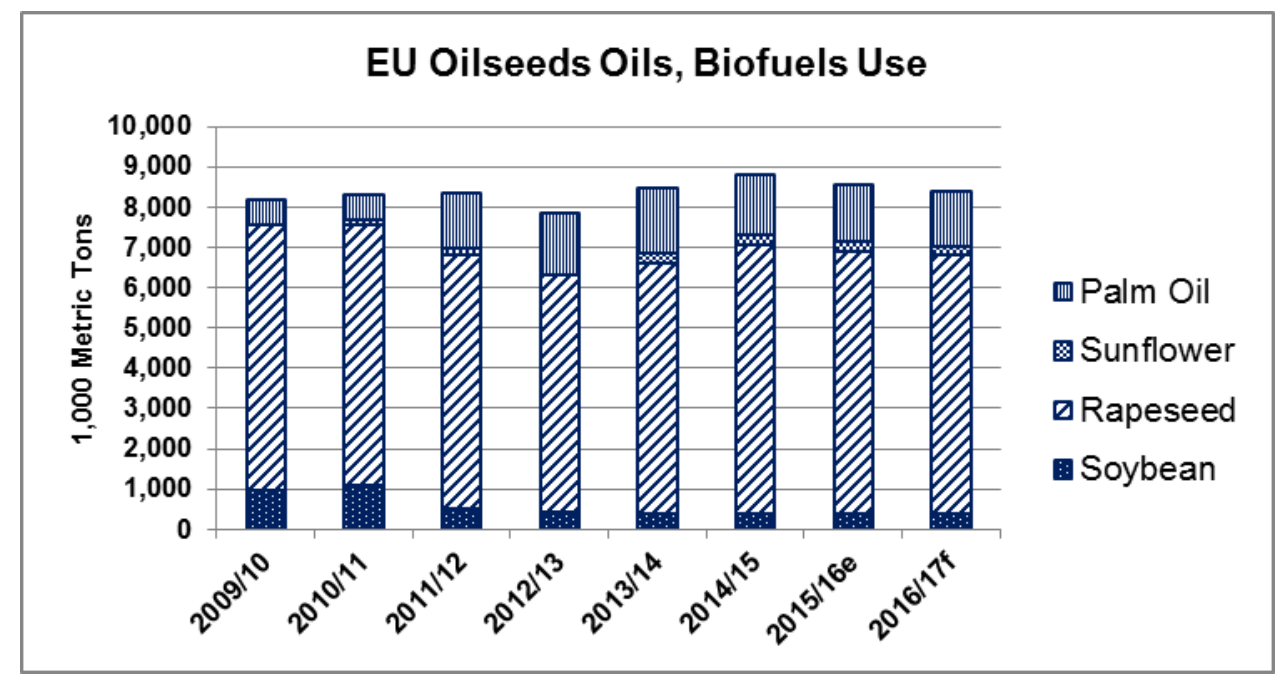

Source: FAS EU-28 


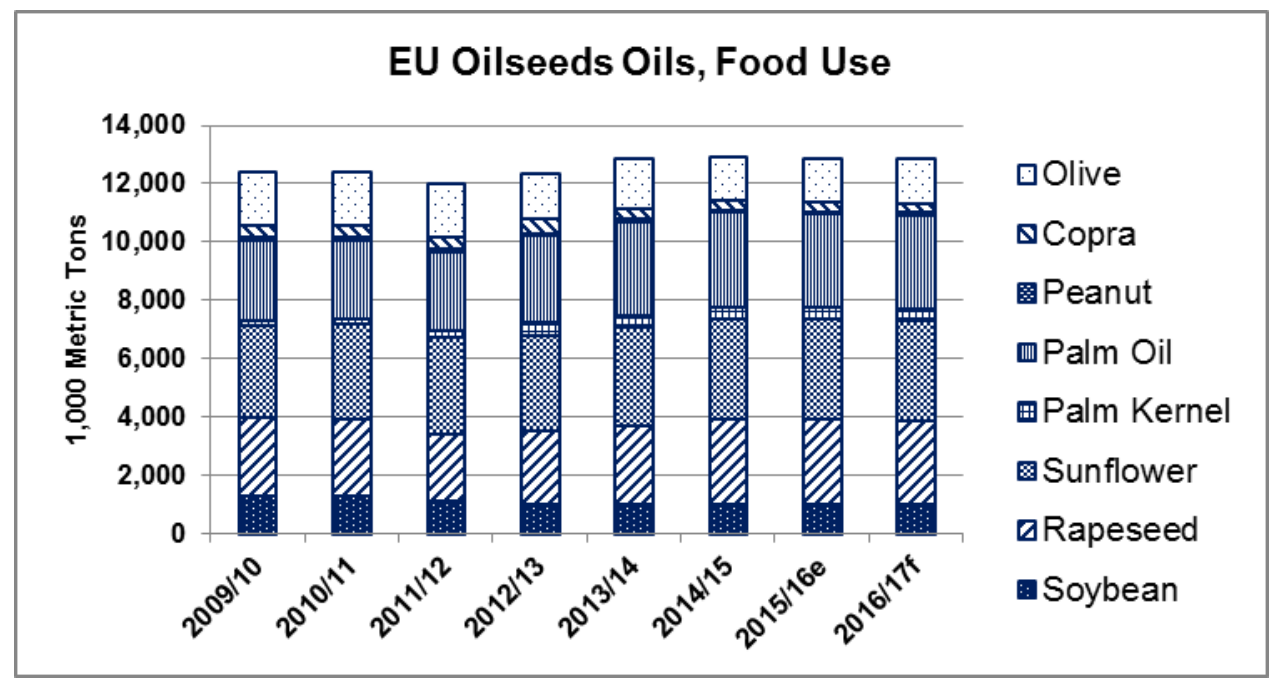

Source: FAS EU-28

\section{Soybean Complex}

Coordinator: Lucile Lefebvre, FAS/Paris

\section{Soybean Seeds}

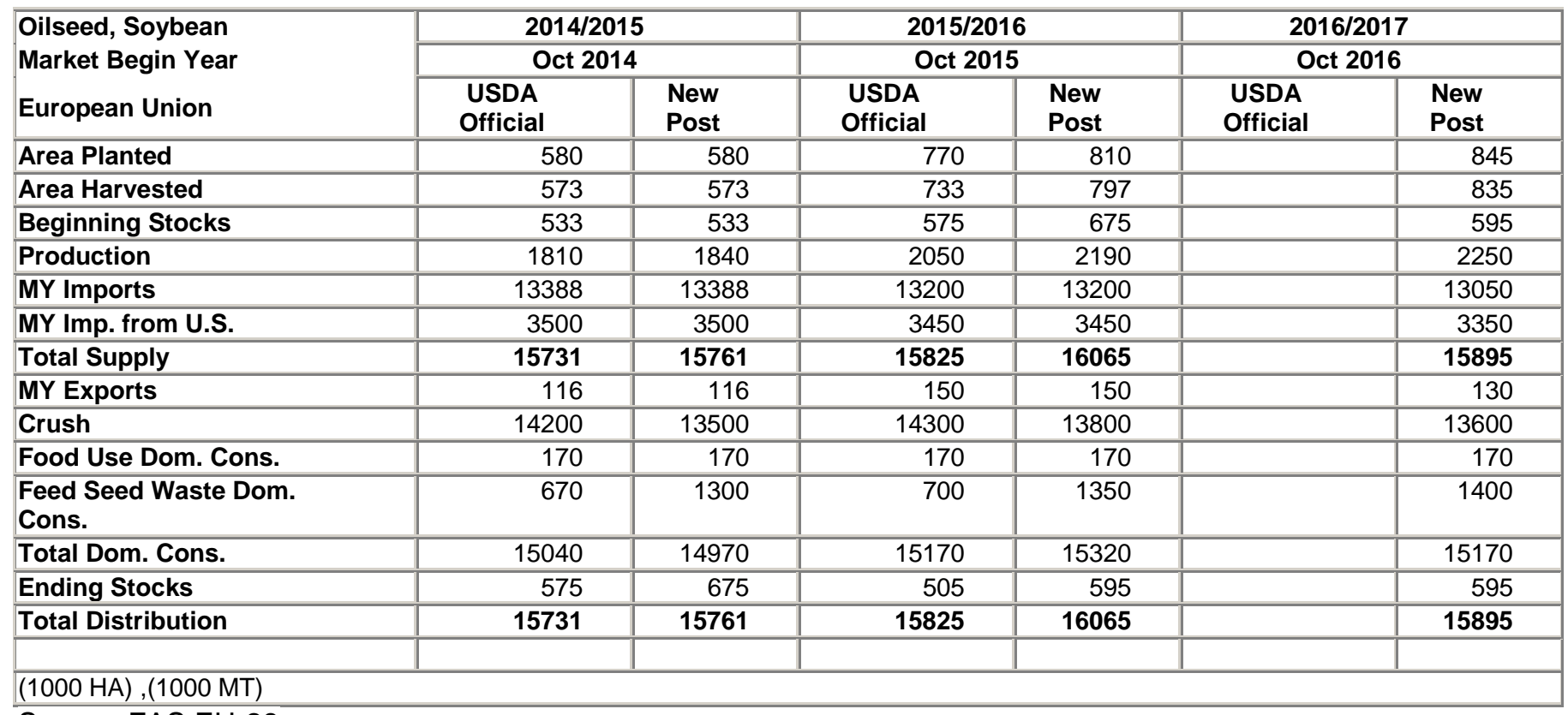

Source: FAS EU-28

\section{MY 2016/17}

In MY 2016/17, soybean production keeps increasing in the EU but at a slower pace than in MY 2015/16. The rise is mainly driven by public policies (Common Agricultural Policy ecological focus areas and coupled payments). Total production should reach 2.25 MMT (a 2.7 percent increase compared to MY 2015/16). The area harvested is expected to increase by 38 thousand hectares. A rise is expected in France, Romania, Hungary, Austria, Slovakia, and the Czech Republic while there should be a decline in Italy and Bulgaria. In Bulgaria, the area planted in soybeans is forecast to decline between 10 and 20 percent compared to MY 
2015/16 because disappointing yields and prices as well as difficulties in marketing the soybeans have discouraged some producers. In Italy, yields are likely to decrease after the high level of MY 2015/16.

Domestic production remains marginal compared to imports, which decreased slightly but still account for more than 80 percent of total supply with a high availability of soybeans worldwide. Imports from the U.S. are expected to decline due to the strength of the U.S. dollar and to the devaluation of the peso in Argentina. The rise in production is not expected to offset the decline in imports, resulting in a slight decrease in total supply. Crush should remain below the high level of MY 2015/16 due to lower crush margins.

Regarding feed, seed and waste, the quantity of seeds used in the EU increases because of the rise in the area planted in soybeans. The extrusion and toasting of whole non-biotech soybeans also increase, especially in France, Hungary and Belgium. The full fat soybean meal produced through these techniques is mostly used locally as feed.

\section{MY 2015/16}

In MY 2015/16, the world production of soybeans decreases a little compared to MY 2014/15 but stocks are higher and consumption keeps growing. In the EU, soybean production increases by 19 percent to reach 2.19 MMT. This rise is mainly driven by public policies. We recommend raising USDA official production estimate, which is lower than the sum of the figures provided by FAS posts in the EU.

EU imports decrease slightly compared to MY 2014/15 but they still account for more than 80 percent of total supply.

Soybean crush increases. This is supported by low crush margins for rapeseed, a decline in rapeseed production, a high availability of soybeans on the world market, as well as good crush margins for soybeans in October and December 2015. Moreover, following the increase in domestic soybean production, crushing capacity rises in some countries.

As in MY 2016/17, the rise in feed, seed and waste figures is driven by the increase in domestic production. Based on member states' estimates, numbers in MY 2015/16 and MY 2014/15 for crush have been revised down and the quantity of full fat soybeans in feed has been revised up compared to previous USDA official numbers.

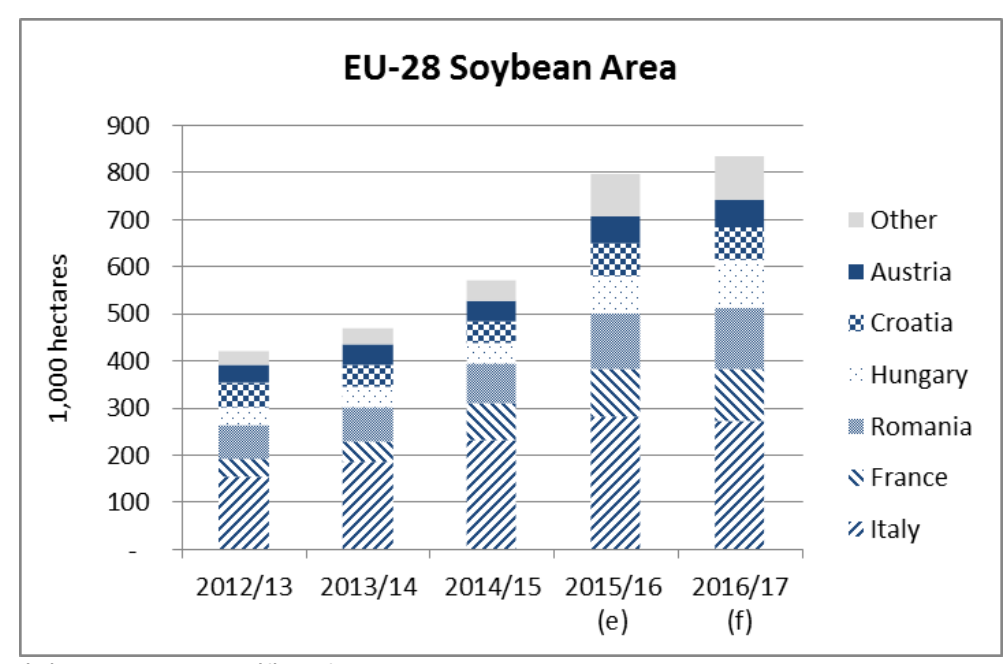

$(e)=$ estimate; $(f)=$ forecast

Source: FAS Posts 


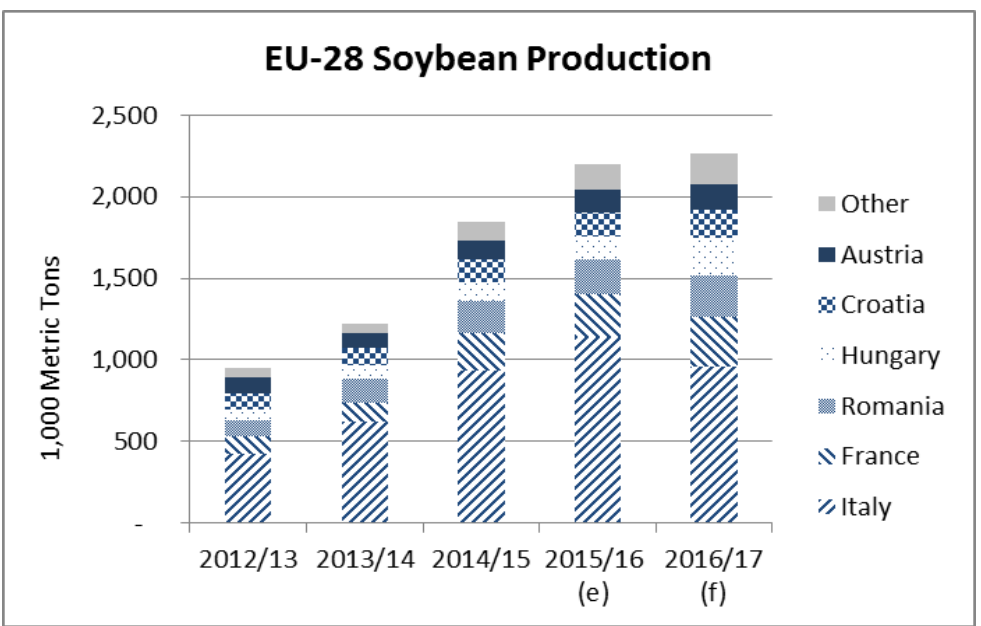

$(\mathrm{e})=$ estimate; $(\mathrm{f})=$ forecast

Source: FAS Posts

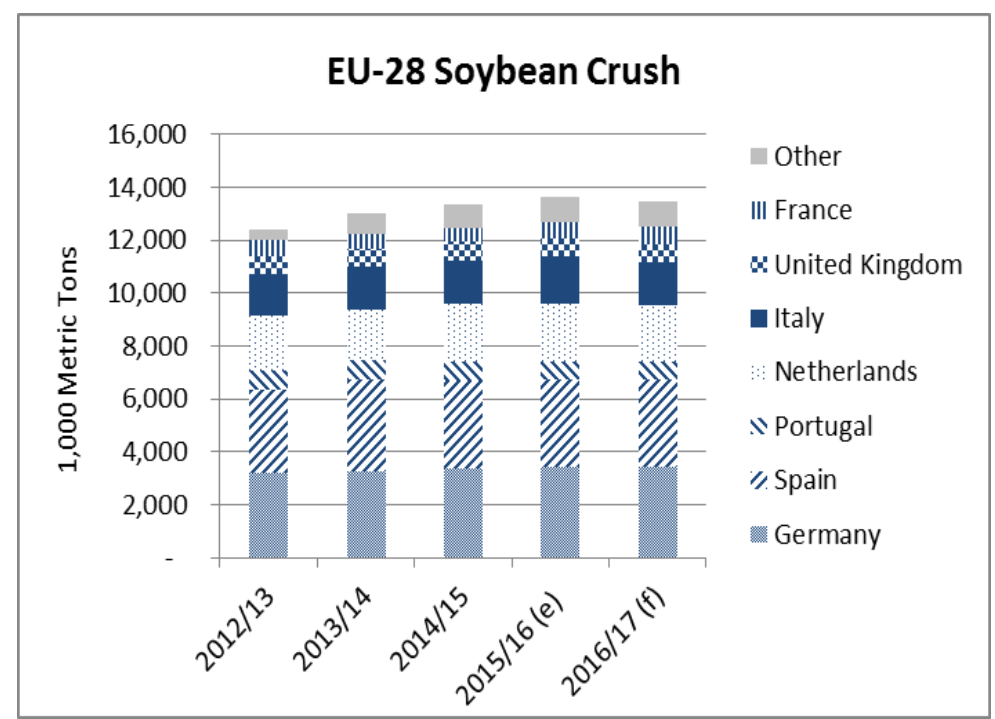

$(e)=$ estimate; $(f)=$ forecast

Source: FAS Posts 


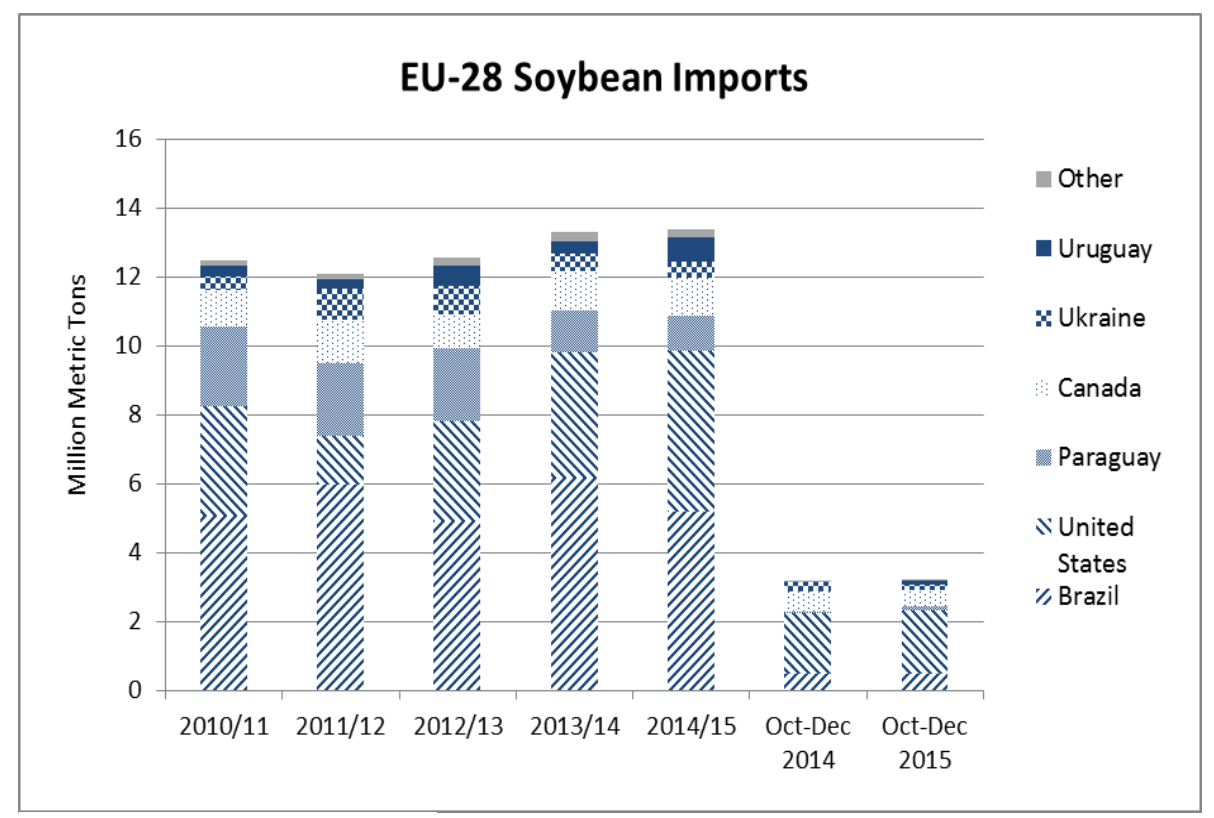

Source: Global Trade Atlas

\section{Soybean Meal}

\begin{tabular}{|c|c|c|c|c|c|c|}
\hline \multirow{3}{*}{$\begin{array}{l}\text { Meal, Soybean } \\
\text { Market Begin Year } \\
\text { European Union }\end{array}$} & \multirow{2}{*}{\multicolumn{2}{|c|}{$\begin{array}{c}2014 / 2015 \\
\text { Oct } 2014\end{array}$}} & \multirow{2}{*}{\multicolumn{2}{|c|}{$\begin{array}{c}2015 / 2016 \\
\text { Oct } 2015\end{array}$}} & \multirow{2}{*}{\multicolumn{2}{|c|}{$\begin{array}{c}2016 / 2017 \\
\text { Oct } 2016\end{array}$}} \\
\hline & & & & & & \\
\hline & $\begin{array}{l}\text { USDA } \\
\text { Official }\end{array}$ & $\begin{array}{l}\text { New } \\
\text { Post }\end{array}$ & $\begin{array}{l}\text { USDA } \\
\text { Official }\end{array}$ & $\begin{array}{l}\text { New } \\
\text { Post }\end{array}$ & $\begin{array}{l}\text { USDA } \\
\text { Official }\end{array}$ & $\begin{array}{l}\text { New } \\
\text { Post }\end{array}$ \\
\hline Extr. Rate, 999.9999 & 0.79 & 0.78 & 0.7902 & 0.779 & & 0.7794 \\
\hline Beginning Stocks & 261 & 261 & 235 & 347 & & 485 \\
\hline Production & 11218 & 10530 & 11300 & 10750 & & 10600 \\
\hline Total Supply & 30739 & 30051 & 32235 & 31397 & & 31585 \\
\hline MY Exports & 362 & 362 & 400 & 370 & & 380 \\
\hline Industrial Dom. Cons. & 10 & 10 & 10 & 10 & & 10 \\
\hline Food Use Dom. Cons. & 32 & 32 & 32 & 32 & & 32 \\
\hline $\begin{array}{l}\text { Feed Seed Waste Dom. } \\
\text { Cons. }\end{array}$ & 30100 & 29300 & 31600 & 30500 & & 30700 \\
\hline (1000 MT), (PERCENT) & & & & & & \\
\hline
\end{tabular}

\section{Source: FAS EU-28}

\section{MY 2016/17}

In MY 2016/17, the production of soybean meal is expected to decrease in the EU due to lower crush. Imports should more than offset the decline in production, leading to a total supply slightly higher than in MY 2015/16. Imports from the U.S. are expected to decline due to the strength of the U.S. dollar and to the devaluation of the peso in Argentina. The rise in total feed demand in the EU is driven by a rise in poultry feed production (especially in the United Kingdom, in Poland, and in France), although the situation varies largely depending on the countries. 


\section{MY 2015/16}

In MY 2015/16, as a consequence of the high level of crush, soybean meal production is expected to increase compared to MY 2014/15. Imports increase as well because of the increase in demand for feed and sufficient availability on the world market.

As a result of lower estimated crush, new estimates for soybean meal production are lower than previous USDA official numbers. Based on more current and more accurate member states' estimates, soybean meal feed use in MY 2015/16 and MY 2014/15 are lowered compared to previous USDA official numbers.

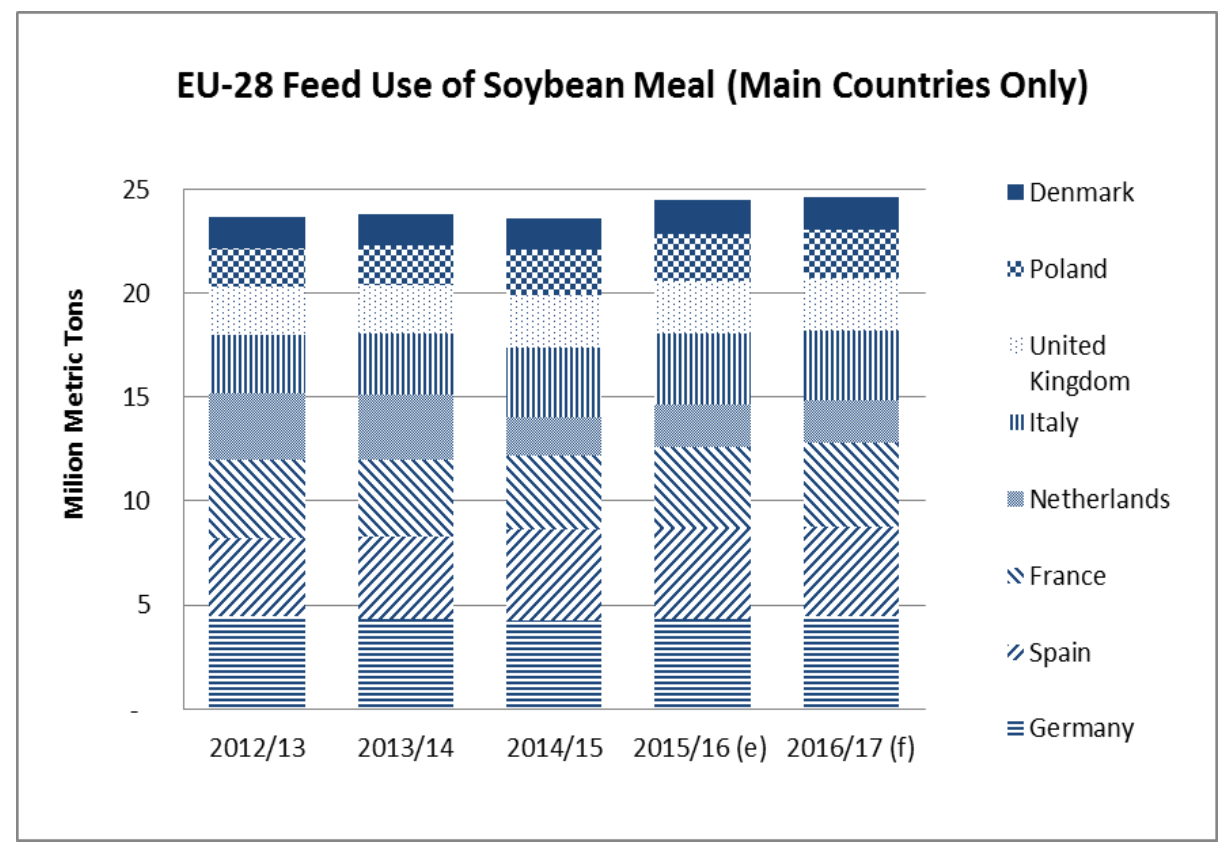

(e) = estimate; $(\mathrm{f})=$ forecast

Source: FAS Posts

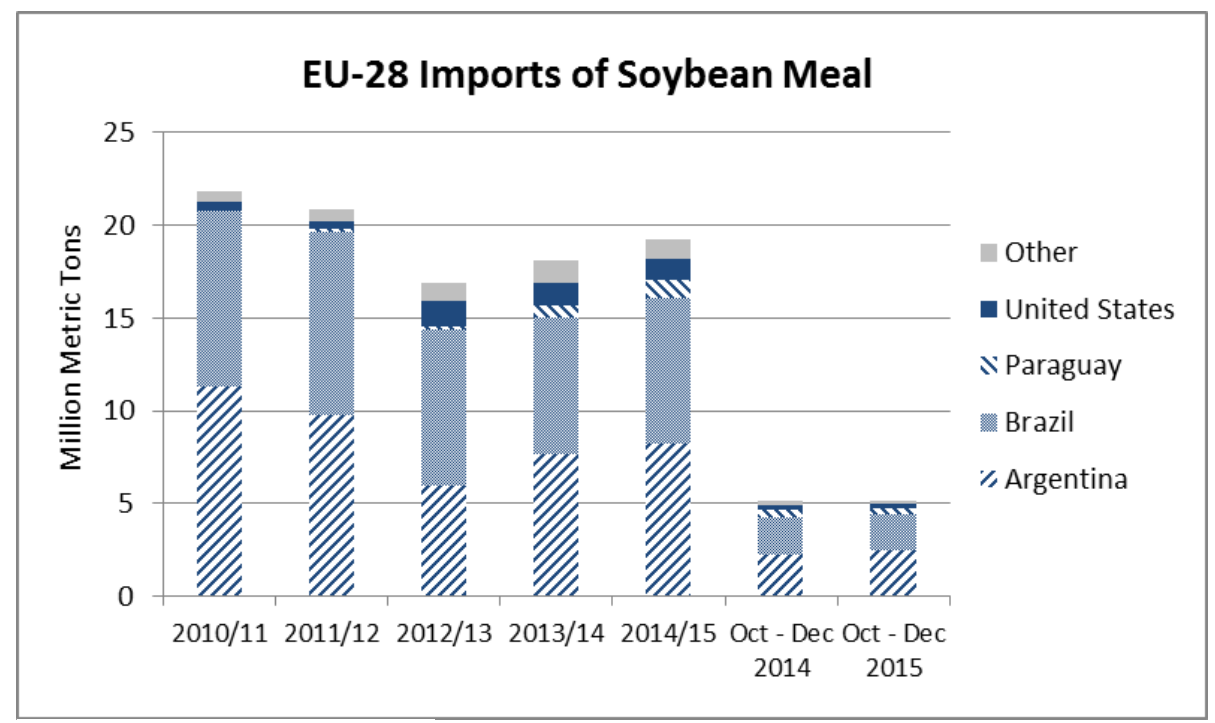

Source: Global Trade Atlas 


\section{Soybean Oil}

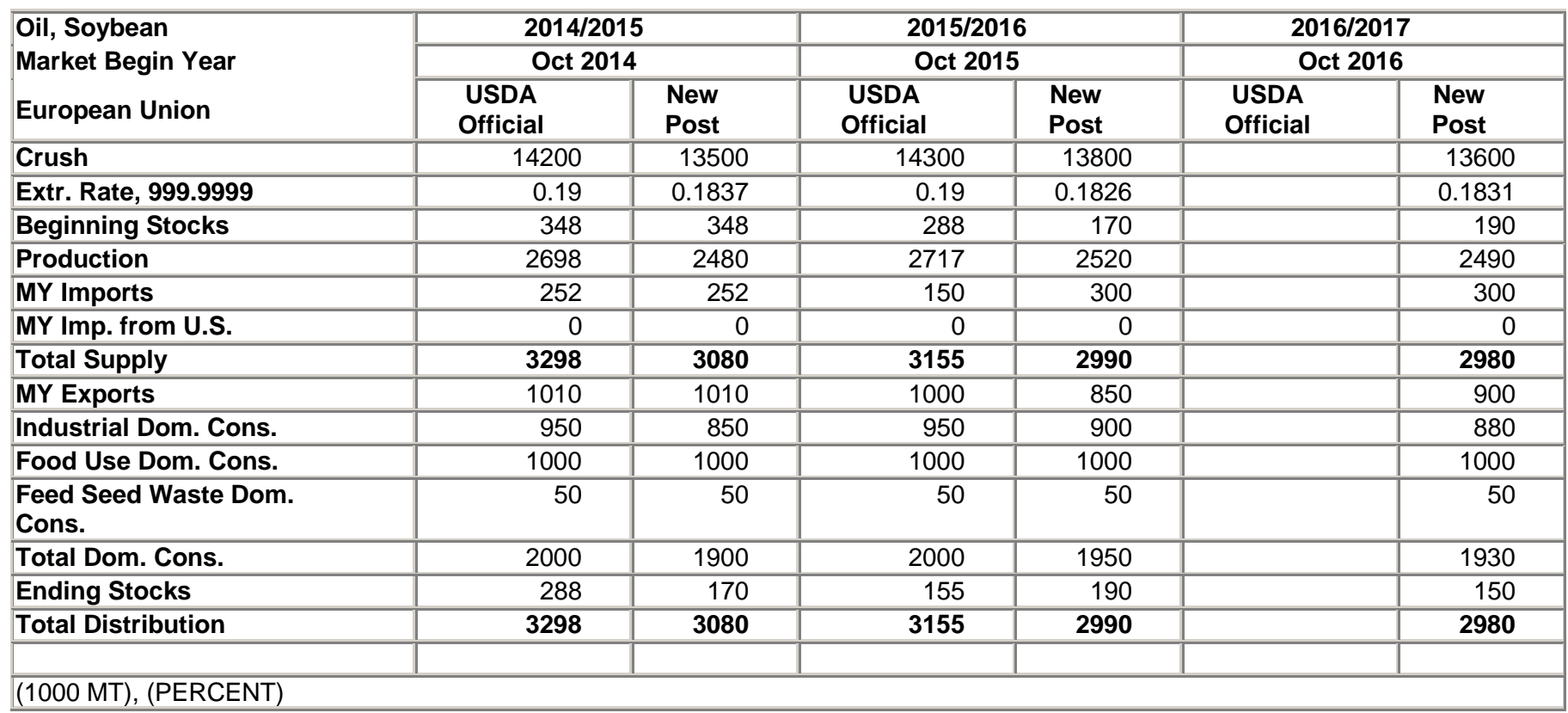

Source: FAS EU-28

\section{MY 2016/17}

In MY 2016/17, the production of soybean oil is expected to decrease in the EU due to lower crush. Imports should remain stable, resulting in a slight decrease in total supply. Industrial consumption is expected to decline slightly while exports should increase.

\section{MY 2015/16}

In MY 2015/16, as a consequence of the high level of crush, soybean oil production increases compared to MY 2014/15. Imports rise too because of the increase in industrial demand and sufficient availability on the world market, while exports are lower than in MY 2014/15. Given the tight market situation for palm oil, soybean oil partly replaces it in the biodiesel formula. As usual, the excessive supply of soybean oil is exported to third countries, mainly in Africa.

In line with lowered crush numbers, oil production numbers have been revised down compared to previous USDA official numbers. The lower production is expected to lead to increased imports due to a rise in industrial/biofuels consumption. 


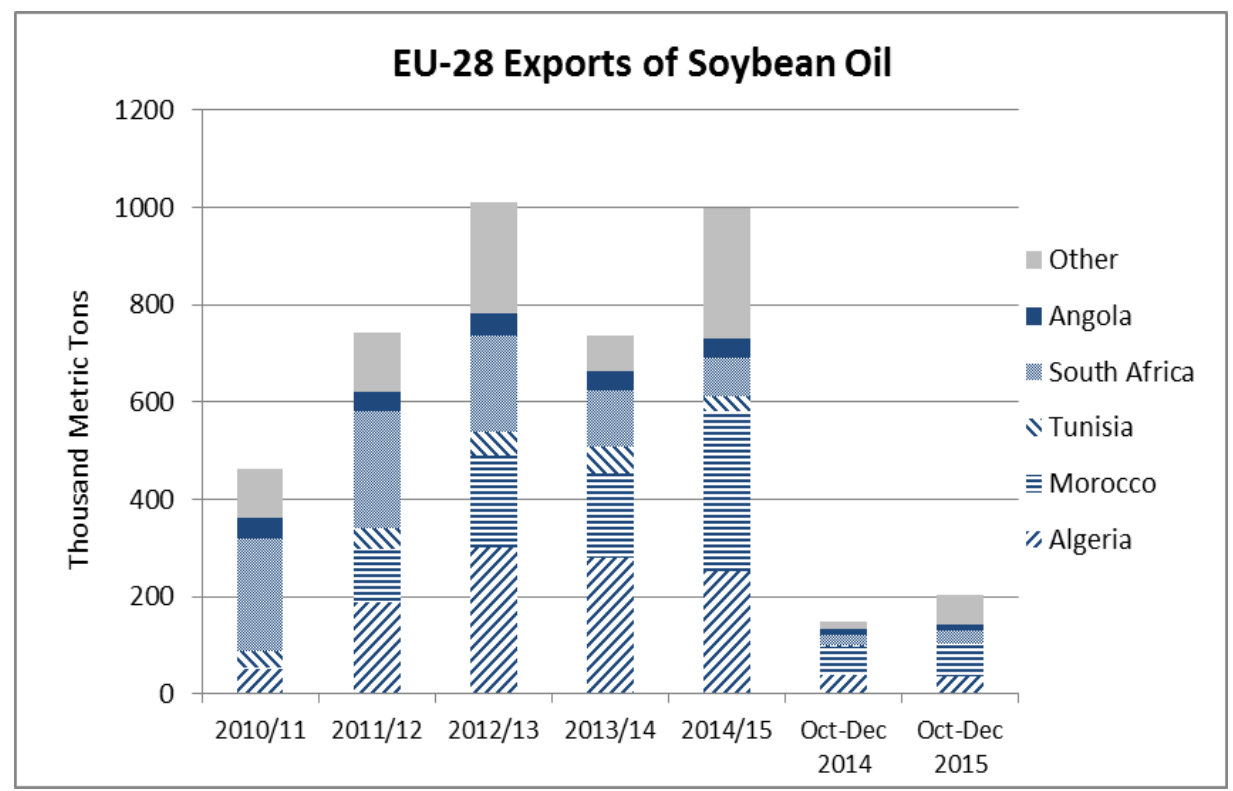

Source: Global Trade Atlas

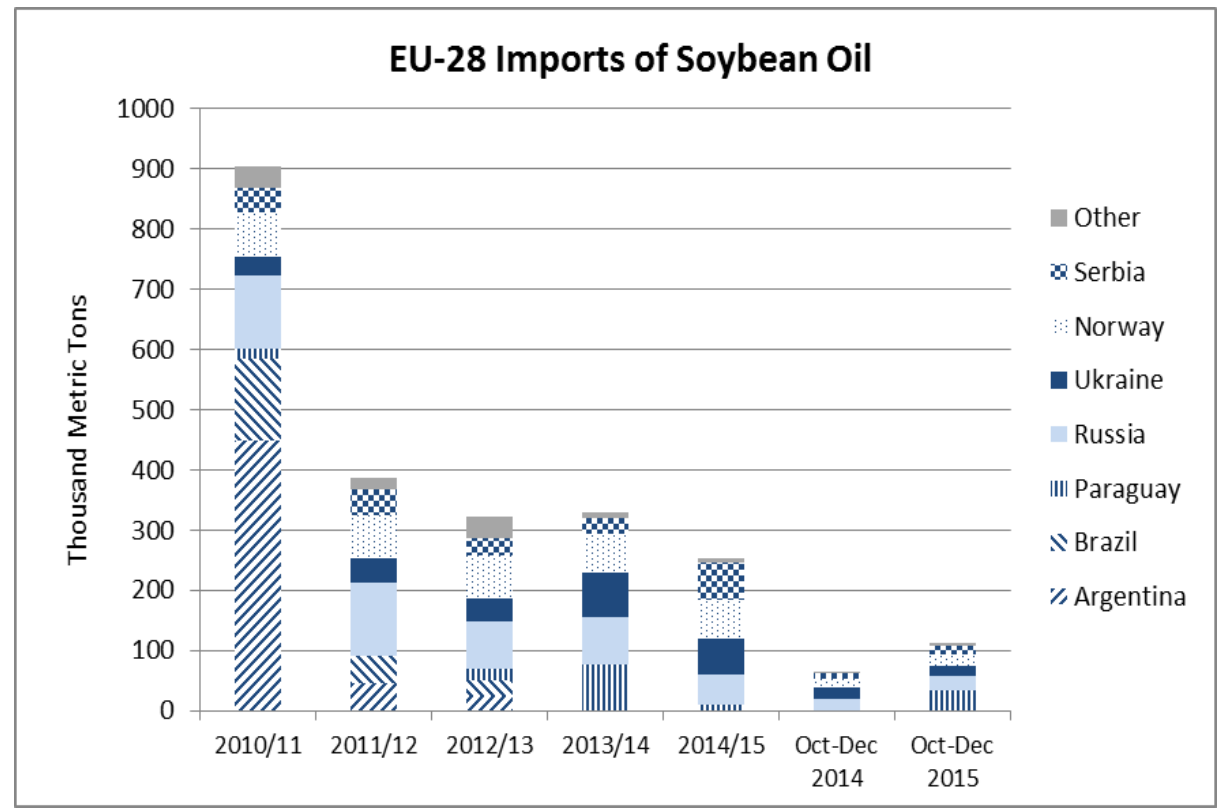

Source: Global Trade Atlas

\section{Rapeseed Complex}

Coordinator: Leif Erik Rehder, FAS/Berlin

The EU is the world's largest producer of rapeseed and products. The two largest producers in the EU are Germany and France, followed by the U.K., Poland, and the Czech Republic. Other major producers include Romania, Denmark, Hungary, Bulgaria and Lithuania. Rapeseed meal is used in the livestock sector as the EU is a leading producer and exporter of meat and dairy products. Main driver for the demand of rapeseed oil is the biodiesel industry, but food and industrial use of rapeseed oil are also influencing demand. 


\section{Rapeseed Seeds}

\begin{tabular}{|c|c|c|c|c|c|c|}
\hline Oilseed, Rapeseed & $2014 /$ & & 2015/ & & $2016 /$ & \\
\hline Market Begin Year & Jul 2 & & Jul 2 & & Jul 2 & \\
\hline European Union & USDA Official & New Post & USDA Official & New Post & USDA Official & New Post \\
\hline Area Planted & 6760 & 6760 & 6580 & 6580 & 0 & 6600 \\
\hline Area Harvested & 6755 & 6746 & 6576 & 6493 & 0 & 6600 \\
\hline Beginning Stocks & 1888 & 1888 & 1752 & 1767 & 0 & 1317 \\
\hline Production & 24450 & 24500 & 21800 & 22050 & 0 & 22400 \\
\hline MY Imports & 2317 & 2317 & 2800 & 2800 & 0 & 2300 \\
\hline MY Imp. from U.S. & 0 & 0 & 0 & 0 & 0 & 0 \\
\hline Total Supply & 28655 & 28705 & 26352 & 26617 & 0 & 26017 \\
\hline MY Exports & 588 & 588 & 300 & 300 & 0 & 350 \\
\hline Crush & 25365 & 25400 & 24300 & 24100 & 0 & 24000 \\
\hline Food Use Dom. Cons. & 0 & 0 & 0 & 0 & 0 & 0 \\
\hline Feed Waste Dom. Cons. & 950 & 950 & 950 & 900 & 0 & 900 \\
\hline Total Dom. Cons. & 26315 & 26350 & 25250 & 25000 & 0 & 24900 \\
\hline Ending Stocks & 1752 & 1767 & 802 & 1317 & 0 & 767 \\
\hline Total Distribution & 28655 & 28705 & 26352 & 26617 & 0 & 26017 \\
\hline
\end{tabular}

Europe's demand for rapeseed exceeds its domestic supply which leads to the import of large quantities of rapeseed for crushing. Together, Ukraine and Australia account for roughly $90 \%$ of European rapeseed imports. However, supply on the global rapeseed market has become tight and the outlook is stable. The export potential of Australia and Ukraine is expected to be limited. Thus, crushers started to look for other sources and there is a rebound of imports from Canada.

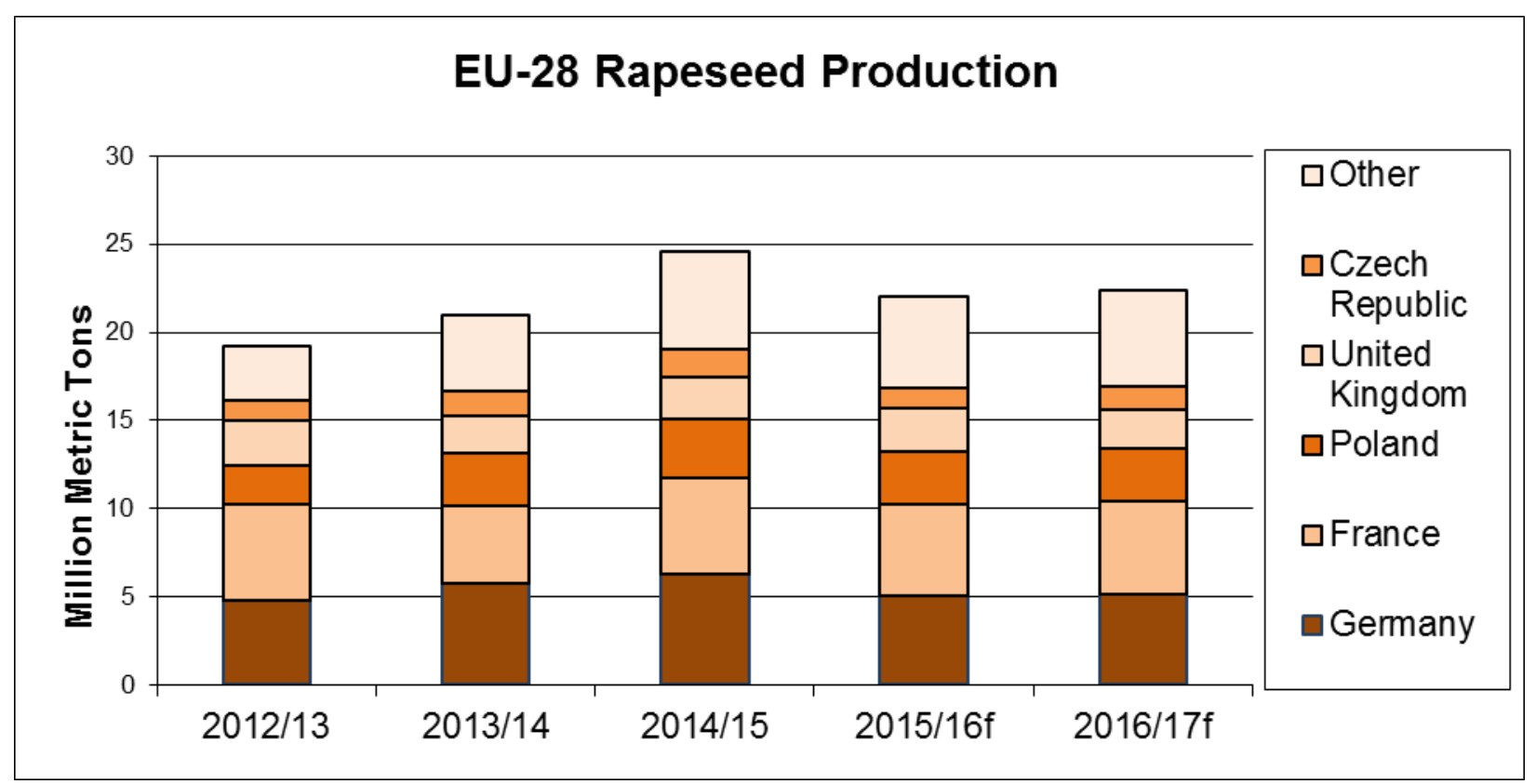

Source: FAS EU-28; f: forecast

In recent years, imports from Canada were limited due to the fact that it produces GMO rapeseed. Now, Canada's rapeseed industry has established and started using the International Sustainability and Carbon Certification (ISCC) system. ISCC meets Europe's criteria in the Renewable Energy Directive. This resulted in a steep increase of Canadian rapeseed imports since crushers in Europe are using GMO rapeseed to a certain extent. 


\section{MY 2016/17}

European farmers planted more rapeseed in MY 2016/17 and the EU area is expected to increase by nearly 2 percent to 6.6 million ha. The higher acreage is mainly due to increases in Romania, Lithuania and Latvia as well as the Czech Republic and to a lesser extent in Estonia and Denmark. High rapeseed prices and favorable planting conditions in autumn led to a steep increase of rapeseed plantings in Romania. Farmers in the Baltic countries planted more rapeseed since export demand for biofuel on the European market is growing. While area planted to rapeseed in Spain is still small, area continues to grow year after year driven by the Portuguese biofuel industry's demand. The only significant decrease in the EU is forecast for the U.K. Here, farmers planted over 50,000 hectares less rapeseed due to low prices. The total cost of production virtually matches the basic ex-farm price for rapeseed in the U.K.

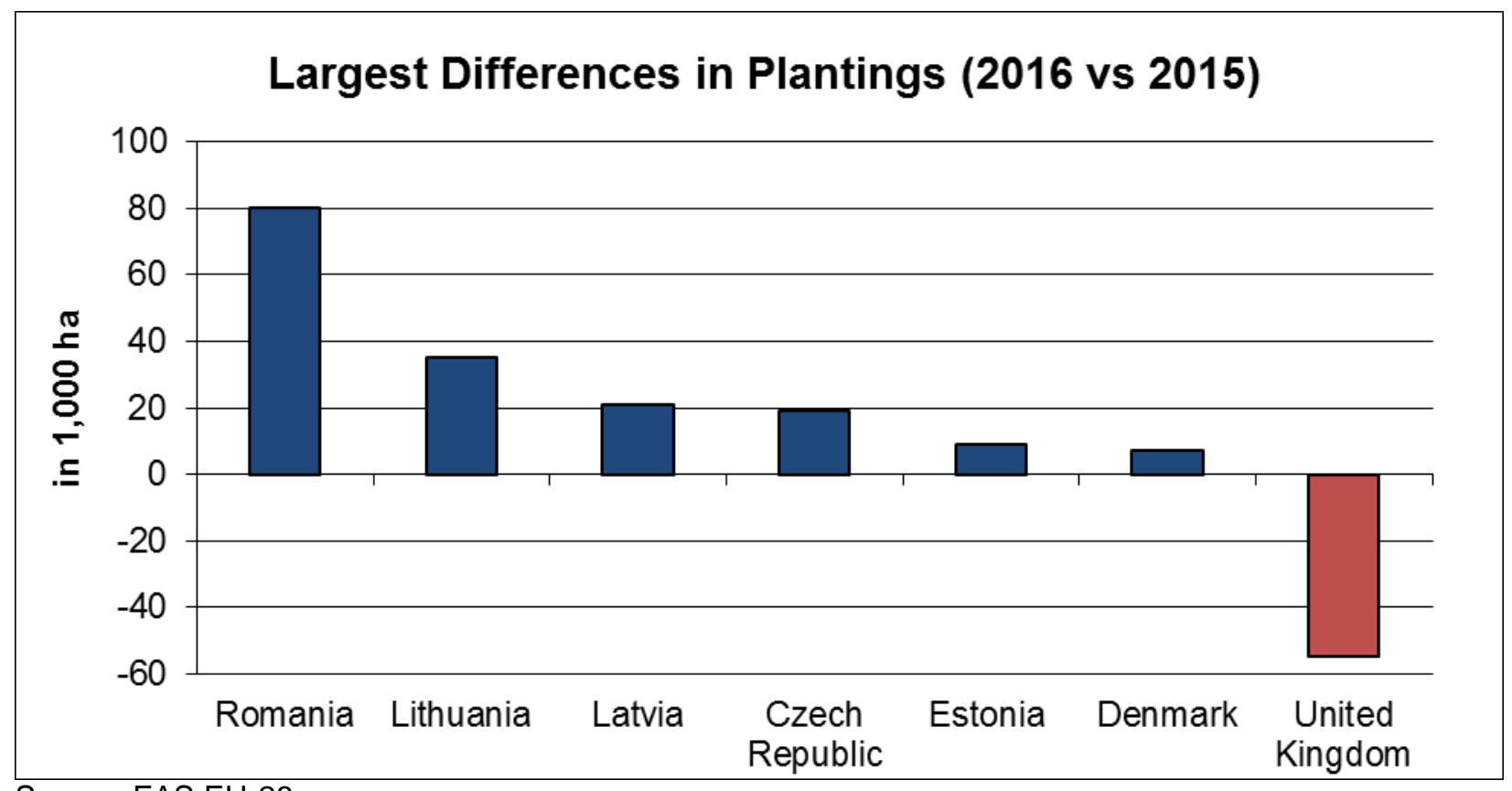

Source: FAS EU-28

In general, growing conditions for rapeseed in Europe have been extremely good with little winterkill. A cold wave in January did not cause much damage in some areas of Poland, Hungary, Lithuania, Latvia and Germany. The warm winter might increase insect infestation and disease pressure. In general, yield is expected to be slightly better than last year without reaching record levels from 2014. However, weather conditions in April and May will determine the final quality and yield of the European rapeseed crop.

Total EU-28 rapeseed production is currently forecast at 22.40 MMT in MY 2016/17, which is nearly 2 percent higher than the production estimate for 2015/16. Imports are expected to decrease since global supply of rapeseed is expected to be tight. Exports are expected to increase slightly due to production gains in Romania which will partly be shipped to Turkey. One important factor for the European rapeseed market is the competition with other oilseeds. Worldwide, scenarios show an ample supply and low prices for soybeans. Rapeseed crush in MY 2016/17 is expected to decrease slightly to 24 MMT due to low supplies and continued low crush margins. Tight rapeseed supply on the European market will partly be offset by stocks and ending stocks are expected to decrease further.

\section{MY 2015/16}

EU rapeseed production had to be revised upwards since harvest in Poland, the U.K., Denmark, Romania, France and Hungary turned out better than expected. In total, European rapeseed production is expected to reach 22.05 MMT in MY 2015/16, down 10 percent from the record levels of the previous MY. The main factors in this decline was that European farmers planted 250,000 hectares less rapeseed and yields were also lower. 
Smaller supply of domestically produced rapeseed has led to a tight European market. At the same time, the export surplus of Ukraine and Australia is limited but there is a rebound in exports from Canada.

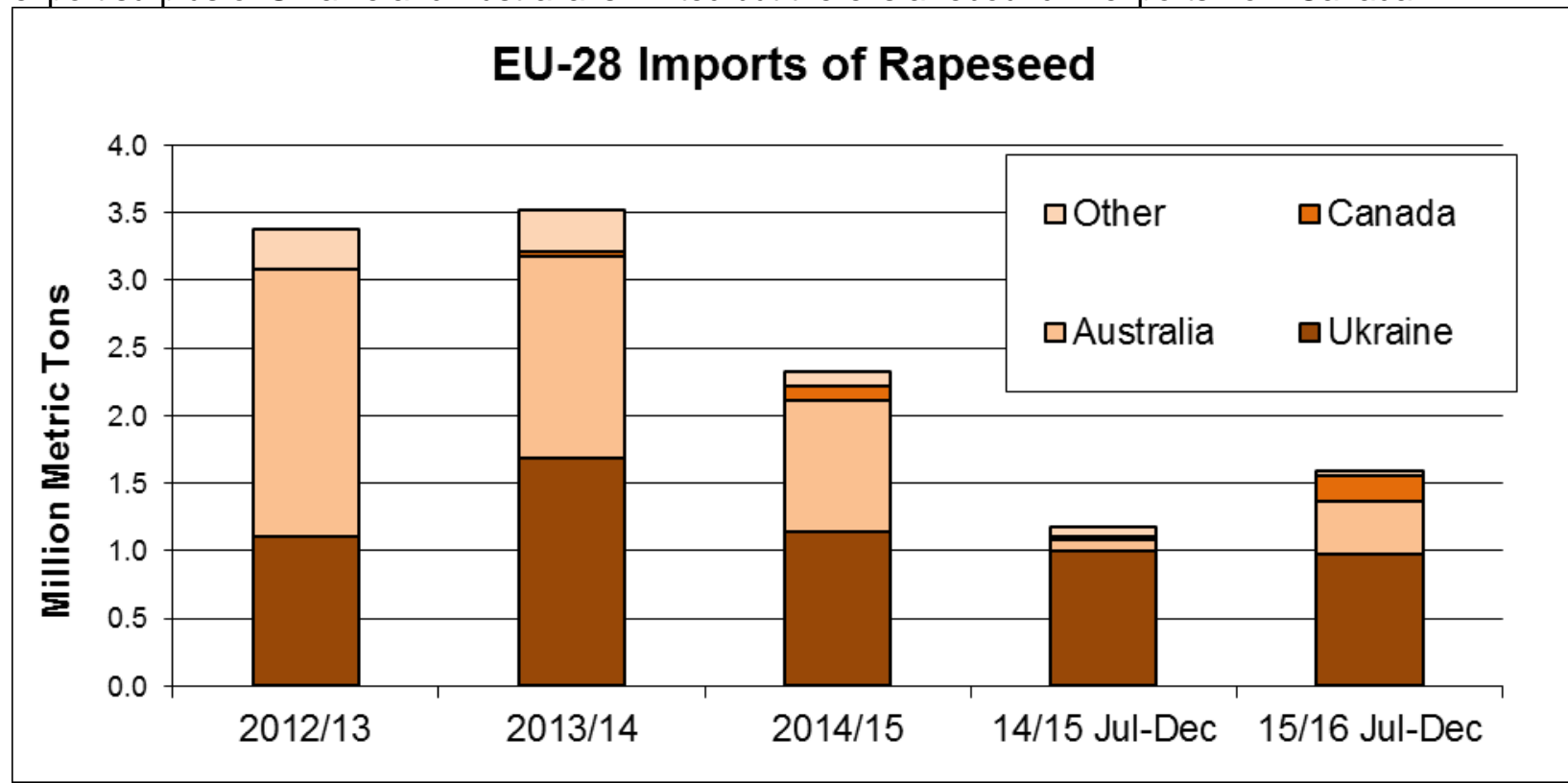

Global Trade Atlas and FAS EU-28

At the same time, there is an ample global supply of soybeans for competitive prices. If possible, oil mills crush soybeans instead of rapeseed. Crushing of rapeseed in the European Union has already decreased in the first half of MY 2015/16 due to tight supply and low crush margins and there is no upward potential for the remaining half of MY 2015/16. In total, rapeseed crush is expected to drop by over 5 percent to 24.1 MMT in the current MY. Ending stocks are expected to decrease by the end of MY 2015/16.

\section{MY 2014/15}

Preliminary final data shows a record EU production of 24.50 MMT for rapeseed based on high acreage and exceptional yields. The record production has led to lower imports from Australia and Ukraine. Exports to Turkey, United Arab Emirates and Canada have nearly doubled. European rapeseed crush followed production reaching record levels. Ending stocks were stable.

\section{Rapeseed Meal}

Rapeseed meal production follows crush in MY 2016/17 and decreases slightly. It is expected that rapeseed meal will be replaced by soymeal and grains in feed rations to some extent. However, the demand for rapeseed meal continues to be strong, which is mainly driven by the European dairy sector. The popularity of rapeseed meal for animal feed varies among EU countries. Its use is most prevalent in countries that have a long rapeseed crushing history and high dairy production, like Germany, France, the Benelux and the UK. Since availability of rapeseed meal on the domestic market has become tight exports are expected to decrease slightly. Stocks are also projected to decline. 


\begin{tabular}{|c|c|c|c|c|c|c|}
\hline \multirow{3}{*}{$\begin{array}{l}\text { Meal, Rapeseed } \\
\text { Market Begin Year } \\
\text { European Union }\end{array}$} & \multicolumn{2}{|c|}{$2014 / 2015$} & \multicolumn{2}{|c|}{$2015 / 2016$} & \multicolumn{2}{|c|}{ 2016/2017 } \\
\hline & \multicolumn{2}{|c|}{\begin{tabular}{|l|l|} 
July 2014 \\
\end{tabular}} & \multicolumn{2}{|c|}{\begin{tabular}{|l|} 
July 2015 \\
\end{tabular}} & \multicolumn{2}{|c|}{\begin{tabular}{|l|} 
July 2016 \\
\end{tabular}} \\
\hline & USDA Official & New Post & USDA Official & New Post & USDA Official & New Post \\
\hline Crush & 25365 & 25400 & 24300 & 24100 & 0 & 24000 \\
\hline Extr. Rate, 999.9999 & 0.575 & 0.57 & 0.57 & 0.57 & 0 & 0.57 \\
\hline Beginning Stocks & 205 & 205 & 229 & 322 & 0 & 210 \\
\hline Production & 14586 & 14479 & 13851 & 13738 & 0 & 13680 \\
\hline MY Imports & 452 & 452 & 450 & 450 & 0 & 400 \\
\hline MY Imp. from U.S. & 0 & 0 & 0 & 0 & 0 & 0 \\
\hline Total Supply & 15243 & 15136 & 14530 & 14510 & 0 & 14290 \\
\hline MY Exports & 414 & 414 & 350 & 400 & 0 & 350 \\
\hline Industrial Dom. Cons. & 0 & 0 & 0 & 0 & 0 & 0 \\
\hline Food Use Dom. Cons. & 0 & 0 & 0 & 0 & 0 & 0 \\
\hline Feed Waste Dom. Cons. & 14600 & 14400 & 14050 & 13900 & 0 & 13800 \\
\hline Total Dom. Cons. & 14600 & 14400 & 14050 & 13900 & 0 & 13800 \\
\hline Ending Stocks & 229 & 322 & 130 & 210 & 0 & 140 \\
\hline Total Distribution & 15243 & 15136 & 14530 & 14510 & 0 & 14290 \\
\hline
\end{tabular}

Source: FAS EU-28

\section{Rapeseed Oil}

Biofuel production is a major driver of the European rapeseed market. Changes in EU biofuels policy lead to decreasing use of rapeseed oil for biodiesel. There is strong competition with animal fats and recycled oils. Moreover, low crude oil prices negatively affect the profitability of producing biodiesel from rapeseed oil. In some countries there have been marketing campaigns for food use of rapeseed oil but consumption seems to have peaked in MY 2014/15 and MY 2015/16.

Rapeseed oil production follows crush and total output is expected to decrease slightly in MY 2016/17. Imports are forecast to be stable and exports are projected to decrease slightly due to low availability and competition with other oilseed oils on the global market. Industrial consumption, food use and ending stocks are expected to decrease slightly.

\begin{tabular}{|c|c|c|c|c|c|c|}
\hline \multirow{3}{*}{$\begin{array}{l}\text { Oil, Rapeseed } \\
\text { Market Begin Year } \\
\text { European Union }\end{array}$} & \multicolumn{2}{|c|}{$2014 / 2015$} & \multicolumn{2}{|c|}{$2015 / 2016$} & \multicolumn{2}{|c|}{$2016 / 2017$} \\
\hline & \multicolumn{2}{|c|}{\begin{tabular}{|c|} 
Jul 2014 \\
\end{tabular}} & \multicolumn{2}{|c|}{ Jul 2015} & \multicolumn{2}{|c|}{ Jul 2016} \\
\hline & USDA Official & New Post & USDA Official & New Post & USDA Official & New Post \\
\hline Crush & 25365 & 25400 & 24300 & 24100 & 0 & 24000 \\
\hline Extr. Rate, 999.9999 & 0.415 & 0.417 & 0.415 & 0.417 & 0 & 0.417 \\
\hline Beginning Stocks & 281 & 281 & 438 & 429 & 0 & 199 \\
\hline Production & 10527 & 10593 & 10085 & 10050 & 0 & 10008 \\
\hline MY Imports & 261 & 261 & 250 & 250 & 0 & 250 \\
\hline MY Imp. from U.S. & 2 & 2 & 2 & 0 & 0 & 0 \\
\hline Total Supply & 11069 & 11135 & 10773 & 10729 & 0 & 10457 \\
\hline MY Exports & 356 & 356 & 350 & 330 & 0 & 250 \\
\hline Industrial Dom. Cons. & 7200 & 7400 & 7000 & 7250 & 0 & 7120 \\
\hline Food Use Dom. Cons. & 3050 & 2900 & 3100 & 2900 & 0 & 2850 \\
\hline Feed Waste Dom. Cons. & 25 & 50 & 30 & 50 & 0 & 50 \\
\hline Total Dom. Cons. & 10275 & 10350 & 10130 & 10200 & 0 & 10020 \\
\hline Ending Stocks & 438 & 429 & 293 & 199 & 0 & 187 \\
\hline Total Distribution & 11069 & 11135 & 10773 & 10729 & 0 & 10457 \\
\hline
\end{tabular}

Source: FAS EU-28 
Breakout of EU-28 Industrial Uses for Rapeseed Oil in 1000 MT

\begin{tabular}{|c|c|c|c|}
\hline & MY 2014/15 & MY 2015/16 & MY 2016/17 \\
\hline Biofuels Use & 6,650 & 6,500 & 6,400 \\
\hline Other Industrial Uses & 750 & 750 & 720 \\
\hline Total Industrial Use & 7,400 & 7,250 & 7,120 \\
\hline
\end{tabular}

Source: FAS EU-28

\section{Sunflower Complex}

Coordinator: Mila Boshnakova, FAS/Sofia and Monica Dobrescu, FAS/Bucharest

\section{Sunflower Seeds}

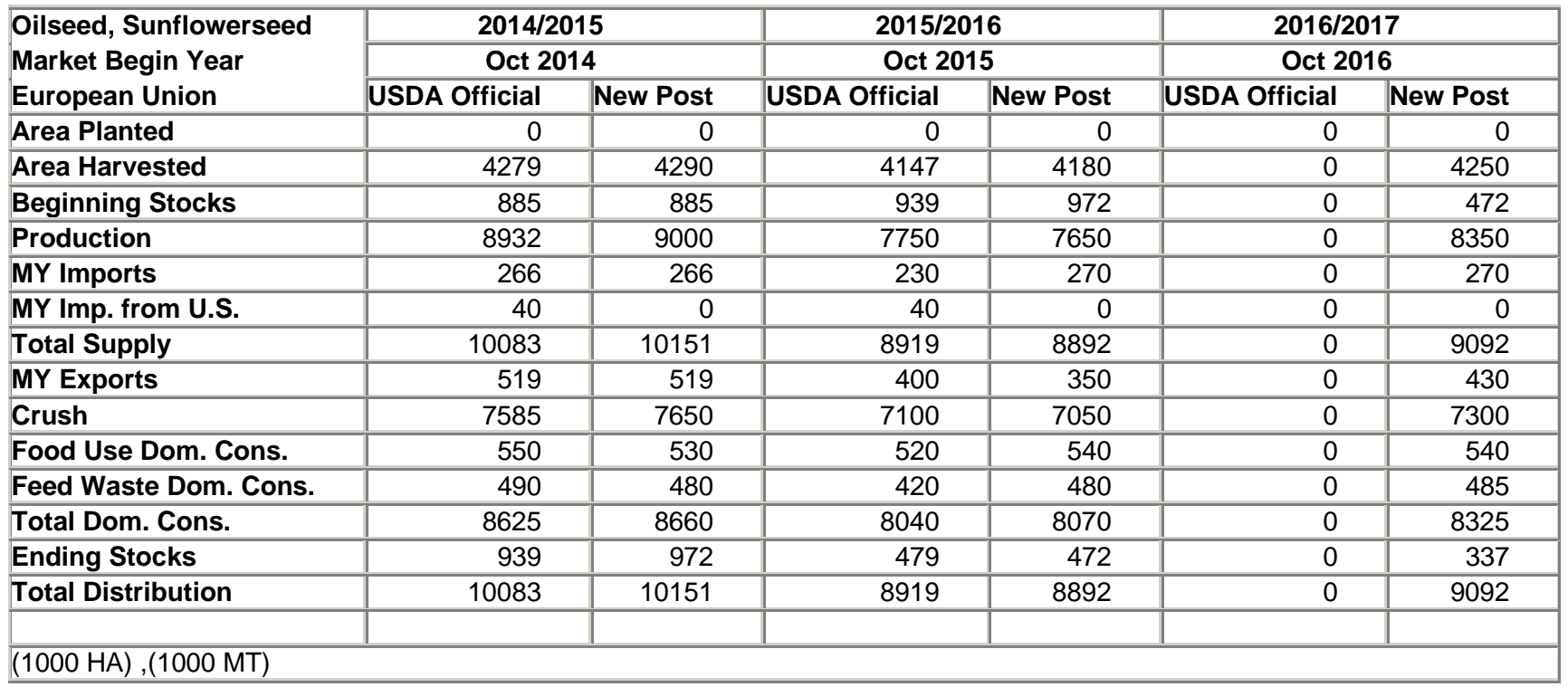

Source: FAS EU-28

\section{MY 2016/17}

The prospects for the sunflower seeds sector in MY 2016/17 in EU-28 are optimistic. Currently farmers plan to expand their planted areas by 1.7 percent and the growth in major producing countries (Spain, Romania and Bulgaria) will exceed slight declines in France, Hungary, and especially in Italy which expects the largest negative growth in the EU. Producers are motivated by better profit margins compared to corn, resilience to heat and drought, expected more favorable crush demand and the opportunity for premiums on specialty types of sunflower such as high oleic, linoleic, and confectionary sunflower. Areas under specialty sunflower are reported to grow in France, Romania, and Bulgaria. France leads this trend with high oleic sunflower accounting for more than 50 percent of French area. Linoleic sunflower represents over 80 percent of Spanish area.

Provided that the weather cooperates, the EU-28 is forecast to produce 9.2 percent more sunflower seeds compared to heat and drought hit supply in MY 2015/16. Good planting conditions are reported in most member states with the exception of Italy and Hungary where there are larger, water-saturated soils. Despite variations in planted areas, all but two (Italy and Portugal) member states expect higher yields and production. 


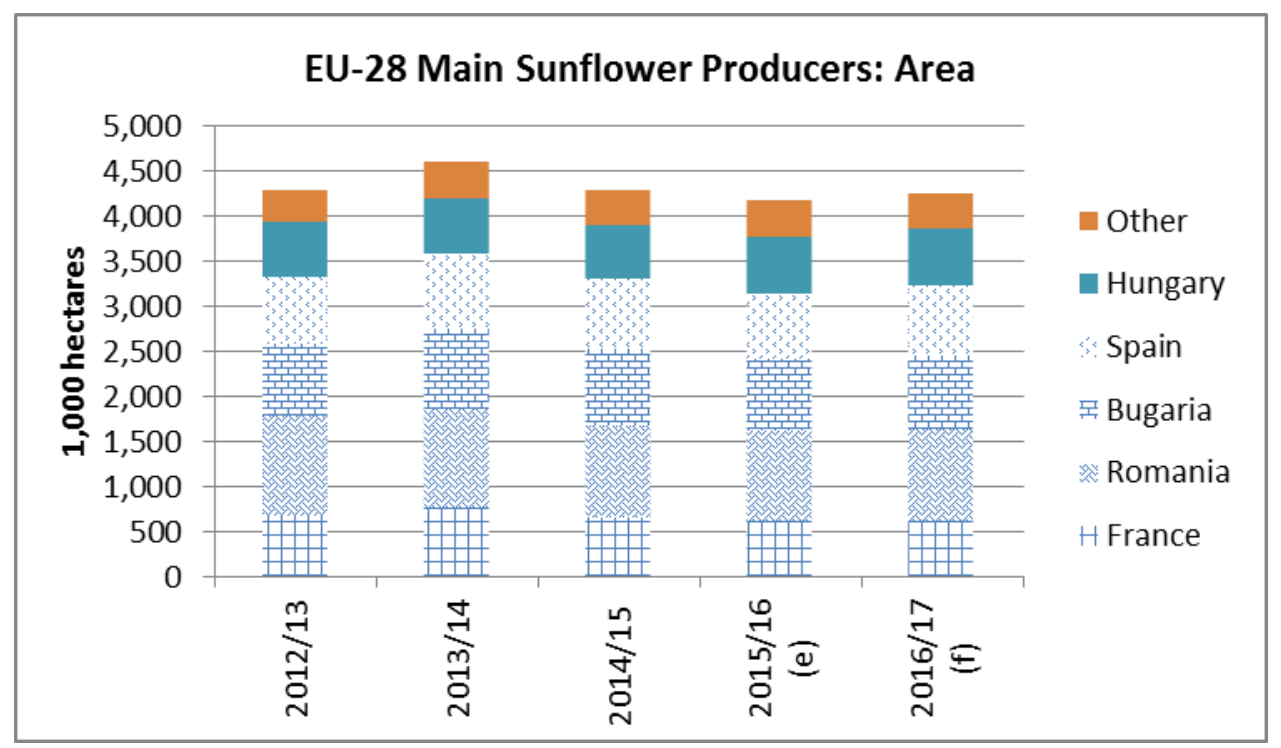

Source: FAS EU-28

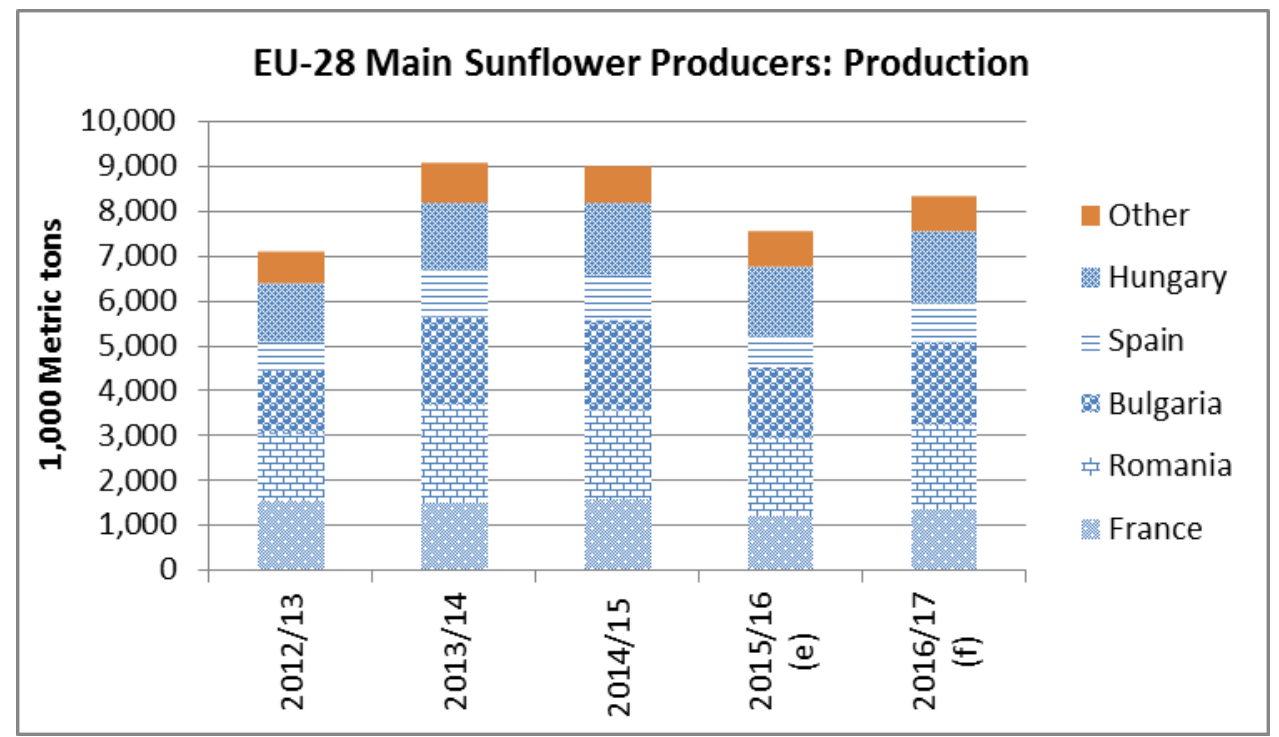

Source: FAS EU-28

Projected higher supply of sunflower seeds in the EU-28 is likely to support a 3.5 percent growth in crush. Crush margins are likely to improve compared to their record tight level in the current marketing year. New or expanding crush capacities (Romania, Bulgaria), however, may see even more pronounced competition in sourcing raw materials between sunflower and expected abundant world supply of soybeans in the new season. 


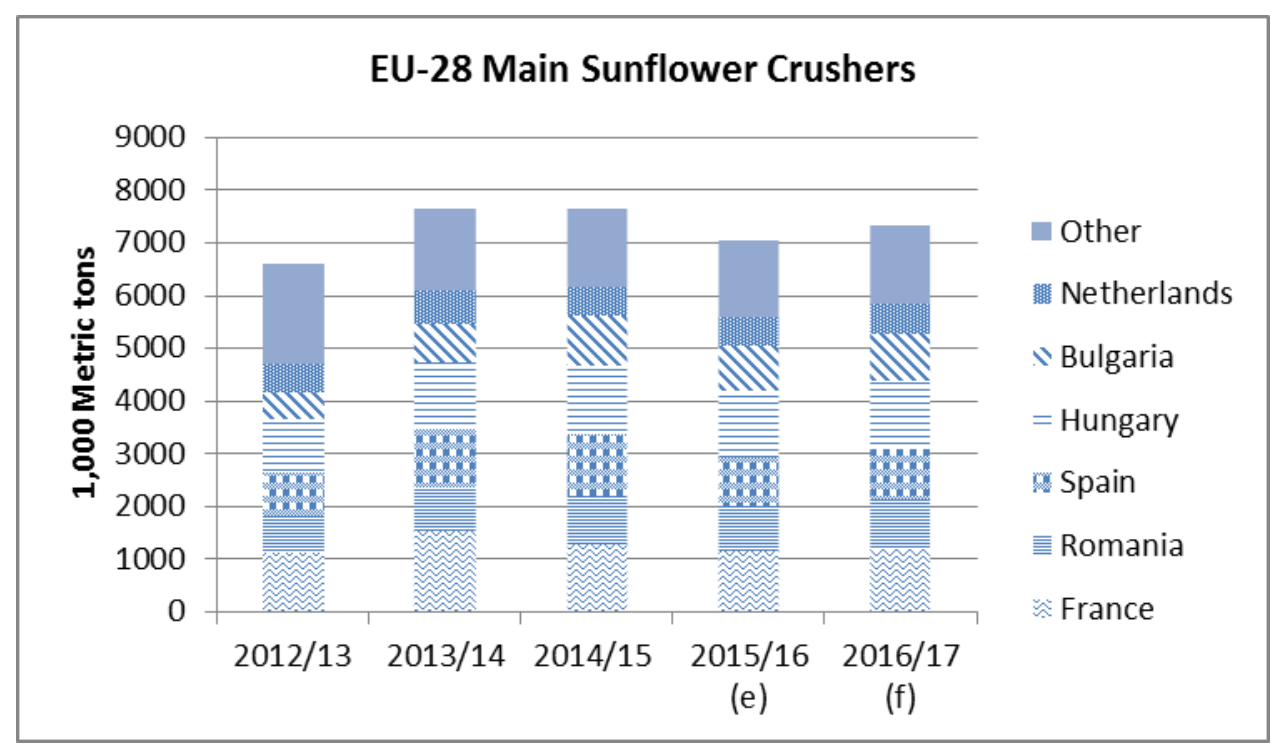

Source: FAS EU-28

The increase in EU-28 sunflower seeds supply is projected to result in stagnant imports and 23 percent higher exports, which along with recovered crush and stable food/feed/waste use, is expected to reduce ending stocks by 29 percent. No significant changes are likely in the trade pattern although Argentina may emerge as a more reliable supplier of sunflower seeds (and/or meal and oil).

\section{MY 2015/16}

The latest EU-28 estimate confirms bigger than previously estimated reduction in production as a result of scorching summer temperatures and drought in most member states. While harvested area remained only slightly lower compared to the previous year, production is estimated to decline to $7.65 \mathrm{MMT}$ or by 15 percent versus MY 2014/15 due to affected yields. This estimate is also below the USDA official data. Sharp decreases in sunflower seeds harvest were reported in Spain, Bulgaria, Romania, and France. Our current estimate has a potential to be revised further downward as not all member states still have final harvest data. Adverse weather also affected quality of the crop being with lower oil content.

The decline in EU-28 sunflower seeds supply led to steep increase in imports by 115 percent in the first quarter of the season. The EU imported seeds from multiple sources such as Ukraine, Russia, Moldova, Serbia and the United States. Later in the season, Argentina also emerged as a supplier of seeds. As a result of its trade regime liberalization and currency reform, Argentine exports of sunflower seeds to the EU have the potential to grow and to be price competitive, especially in the Western part of the EU. Most of EU suppliers have been affected by drought (Moldova, Serbia) or have reduced stocks due to favorable domestic demand (Ukraine, Russia). In addition, current low crush margins in the EU do not motivate strong import demand although the market situation in the second half of the season may marginally improve. Therefore, EU-28 imports of sunflower seeds for MY $2015 / 16$ are estimated to be slightly more than in the previous season.

Lower availability in the EU-28 also resulted in a decline in exports of sunflower seeds. In the first quarter of the marketing year exports were 63 percent lower compared to MY 2014/15. We revised down our annual export estimate and forecast 33 percent decline for this season, below the USDA official estimate. Major export destinations remained Turkey, South Africa, Serbia, and Morocco although in smaller volumes than in the past. Pakistan sharply reduced purchases from the EU.

Current estimates for EU-28 crush consumption show 8 percent decline compared to the previous year and it is marginally below the USDA official estimate. The EU crushing industry continues to face declining and much lower crushing margins compared to the previous seasons and even stronger than previously expected competition from soybeans. Despite the decrease in sunflower seeds prices, meal and oil prices have declined even more under the pressure of competing products, especially due to availability of price-competitive soybean 
meal. Majority member states forecast reduced crush compared to MY 2014/15 (Spain 21 percent, France 12 percent, Portugal 8 percent, Germany 8 percent, Romania 5 percent, Hungary 2 percent, and Bulgaria 10 percent). We expect crush margins to improve moderately in the second half of the season due to alleviated vegetable oil demand and running stocks. Despite the price pressure from other vegetable oils, the EU-28 demand for edible sunflower oil remains good and less price elastic.

As a result of lower availability and adjusted demand, ending stocks are estimated to be less than half of their level in MY 2014/15.

\section{MY 2014/15}

Marginal adjustments were done based on final higher crush data and lower food and feed use.

\section{Sunflower Meal}

\begin{tabular}{|c|c|c|c|c|c|c|}
\hline \multirow{3}{*}{$\begin{array}{l}\text { Meal, Sunflowerseed } \\
\text { Market Begin Year } \\
\text { European Union }\end{array}$} & \multirow{2}{*}{\multicolumn{2}{|c|}{$\begin{array}{c}2014 / 2015 \\
\text { Oct } 2014\end{array}$}} & \multirow{2}{*}{\multicolumn{2}{|c|}{$\begin{array}{c}2015 / 2016 \\
\text { Oct } 2015\end{array}$}} & \multirow{2}{*}{\multicolumn{2}{|c|}{$\begin{array}{c}2016 / 2017 \\
\text { Oct } 2016\end{array}$}} \\
\hline & & & & & & \\
\hline & USDA Official & New Post & USDA Official & New Post & USDA Official & New Post \\
\hline Crush & 7585 & 7650 & 7100 & 7050 & 0 & 7300 \\
\hline Extr. Rate, 999.9999 & 0.543 & 0.5425 & 0.5408 & 0.5418 & 0 & 0.5425 \\
\hline Beginning Stocks & 188 & 188 & 115 & 146 & 0 & 106 \\
\hline Production & 4119 & 4150 & 3840 & 3820 & 0 & 3960 \\
\hline MY Imports & 3210 & 3210 & 3450 & 3170 & 0 & 3150 \\
\hline MY Imp. from U.S. & 0 & 0 & 0 & 0 & 0 & 0 \\
\hline Total Supply & 7517 & 7548 & 7405 & 7136 & 0 & 7216 \\
\hline MY Exports & 302 & 302 & 200 & 230 & 0 & 200 \\
\hline Industrial Dom. Cons. & 0 & 0 & 0 & 0 & 0 & 0 \\
\hline Food Use Dom. Cons. & 0 & 0 & 0 & 0 & 0 & 0 \\
\hline Feed Waste Dom. Cons. & 7100 & 7100 & 7100 & 6800 & 0 & 6900 \\
\hline Total Dom. Cons. & 7100 & 7100 & 7100 & 6800 & 0 & 6900 \\
\hline Ending Stocks & 115 & 146 & 105 & 106 & 0 & 116 \\
\hline Total Distribution & 7517 & 7548 & 7405 & 7136 & 0 & 7216 \\
\hline
\end{tabular}

\section{Source: FAS EU-28}

\section{MY 2016/17}

Sunflower meal supply is forecast to restore increasing by 3.7 percent due to better crush but still to be below the levels achieved in MY 2014/15. Better domestic availability may keep imports stable or slightly lower compared to MY 2015/16. It is projected that the traditional exporters of meal to the EU-28 such as Ukraine, Russia and especially Argentina are likely to have good export potential, on the other hand, competition with abundant and price-competitive soybean meal may be more pronounced. Exports are likely to decline due to expected improved local demand. Overall, sunflower meal use is forecast to recover by less than 2 percent reflecting better supply; however, the growth may be limited by soybean meal competition and generally stagnant feed use. Higher consumption is expected in Spain and Germany (6-7 percent), as well as in France, Romania, Hungary and the UK. 


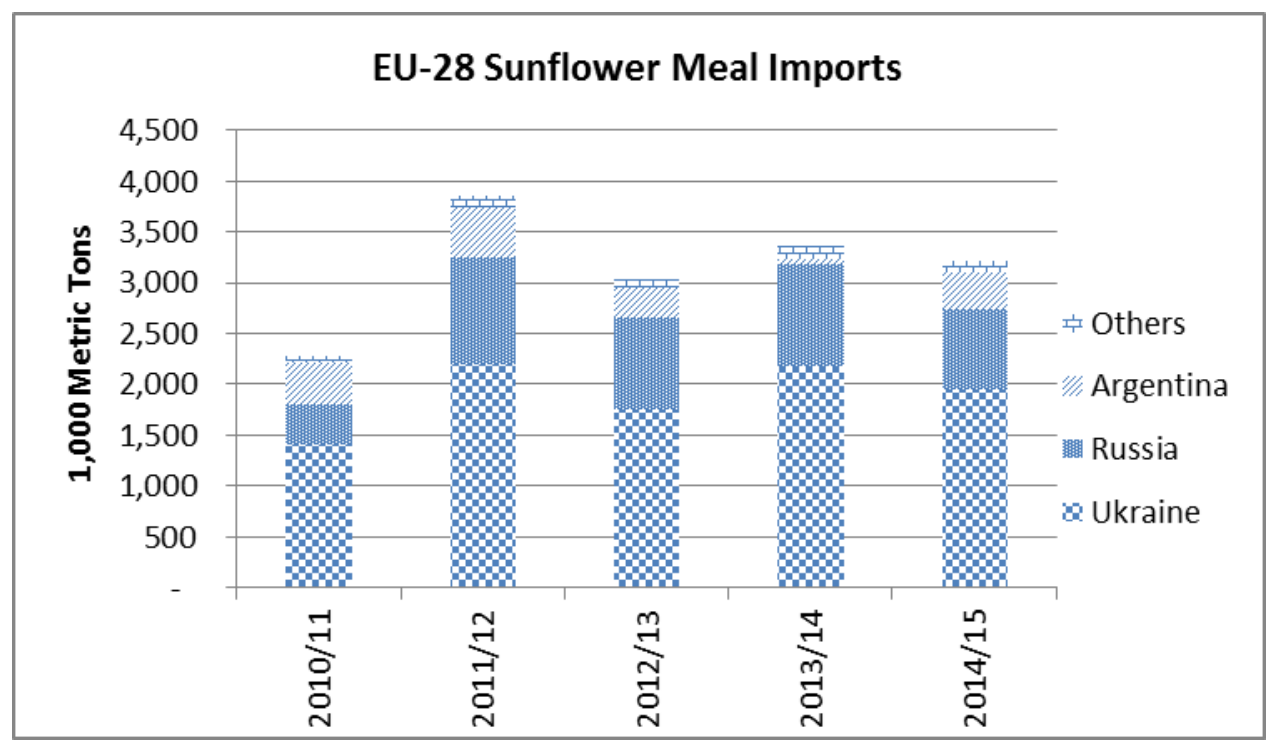

Source: Global Trade Atlas

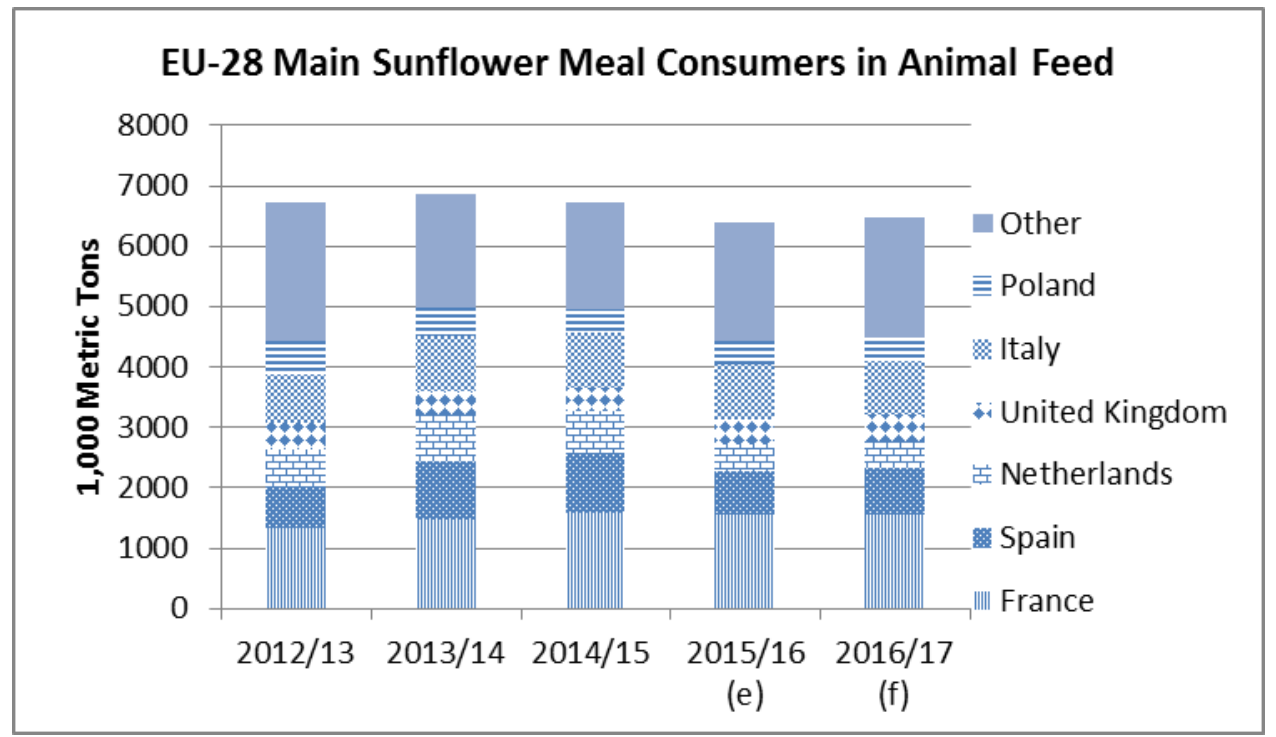

Source: FAS EU-28

\section{MY 2015/16}

The estimate for EU-28 sunflower meal output is forecast to have 8 percent reduction in line with the decline in crush. Despite lower supply, imports may be stable or decrease slightly due to preference towards soybean meal. Imported meal is sourced from the Black Sea suppliers and in the first quarter of the marketing year imports were 3.4 percent less than a year earlier. Exports for the year are forecast to be 25 percent lower compared to MY 2014/15, with a decline of 18 percent in the first quarter of the year due to lower supply and regional Black Sea competition.

After several years of progressive growth in consumption of sunflower meal, the EU-28 use in the current year is projected to decline by 4 percent. Most member states see lower consumption (France, Spain, Germany,

Portugal, Denmark, Poland, the Netherlands, and Bulgaria) which dominates over small growth rates in Romania, Hungary, the UK and Italy. In some member states, there is an increasing use of hi-pro sunflower meal (France, Bulgaria, Hungary) as a substitute of soybean meal in poultry feed ratios. However, sunflower meal consumption is losing its price attractiveness and larger feed producing countries report lower incorporations in feed ratios (The Netherlands, Spain, and Germany). 


\section{MY 2014/15}

Small adjustments were made to sunflower meal production and stocks reflecting final higher crush use.

\section{Sunflower Oil}

\begin{tabular}{|c|c|c|c|c|c|c|}
\hline \multirow{3}{*}{$\begin{array}{l}\text { Oil, Sunflowerseed } \\
\text { Market Begin Year } \\
\text { European Union }\end{array}$} & \multirow{2}{*}{\multicolumn{2}{|c|}{$\begin{array}{c}2014 / 2015 \\
\text { Oct } 2014\end{array}$}} & \multirow{2}{*}{\multicolumn{2}{|c|}{$\begin{array}{c}2015 / 2016 \\
\text { Oct } 2015\end{array}$}} & \multirow{2}{*}{\multicolumn{2}{|c|}{$\begin{array}{r}2016 / 2017 \\
\text { Oct } 2016\end{array}$}} \\
\hline & & & & & & \\
\hline & USDA Official & New Post & USDA Official & New Post & USDA Official & New Post \\
\hline Crush & 7585 & 7650 & 7100 & 7050 & 0 & 7300 \\
\hline Extr. Rate, 999.9999 & 0.4192 & 0.4248 & 0.4197 & 0.4227 & 0 & 0.4233 \\
\hline Beginning Stocks & 251 & 251 & 135 & 205 & 0 & 185 \\
\hline Production & 3180 & 3250 & 2980 & 2980 & 0 & 3090 \\
\hline MY Imports & 823 & 823 & 1000 & 1050 & 0 & 980 \\
\hline MY Imp. from U.S. & 0 & 0 & 0 & 0 & 0 & 0 \\
\hline Total Supply & 4254 & 4324 & 4115 & 4235 & 0 & 4255 \\
\hline MY Exports & 419 & 419 & 300 & 350 & 0 & 370 \\
\hline Industrial Dom. Cons. & 240 & 240 & 230 & 230 & 0 & 230 \\
\hline Food Use Dom. Cons. & 3450 & 3450 & 3460 & 3460 & 0 & 3460 \\
\hline Feed Waste Dom. Cons. & 10 & 10 & 10 & 10 & 0 & 10 \\
\hline Total Dom. Cons. & 3700 & 3700 & 3700 & 3700 & 0 & 3700 \\
\hline Ending Stocks & 135 & 205 & 115 & 185 & 0 & 185 \\
\hline Total Distribution & 4254 & 4324 & 4115 & 4235 & 0 & 4255 \\
\hline (1000 MT),(PERCENT) & & & & & & \\
\hline
\end{tabular}

\section{Source: FAS EU-28}

\section{MY 2016/17}

Sunflower oil supply is forecast to rebound by 3.5 percent reflecting higher crush. Growth rates vary across the EU-28 with higher levels expected in Germany, Romania and Bulgaria (6-8 percent), Spain and France (about 4 percent).

Better availability is likely to result in 7 percent lower imports and 6 percent higher exports in parallel with expected stable sunflower oil consumption. The EU-28 is likely to source sunflower oil from the traditional suppliers (Black Sea players and Argentina) as well as to export to the usual markets (South Africa, Macedonia, Bosnia and Herzegovina).

Sunflower oil is expected to remain a preferred healthy choice (no trans-fats) of food vegetable oil, especially with the expanding supply of hi-oleic sunflower oil. It keeps the potential for higher consumption due to improved use by the food industry and changing consumer choice. Despite this general trend, some member states forecast a potential small decline in consumption (Italy and Czech Republic). Ending stocks are currently expected to remain stable. 


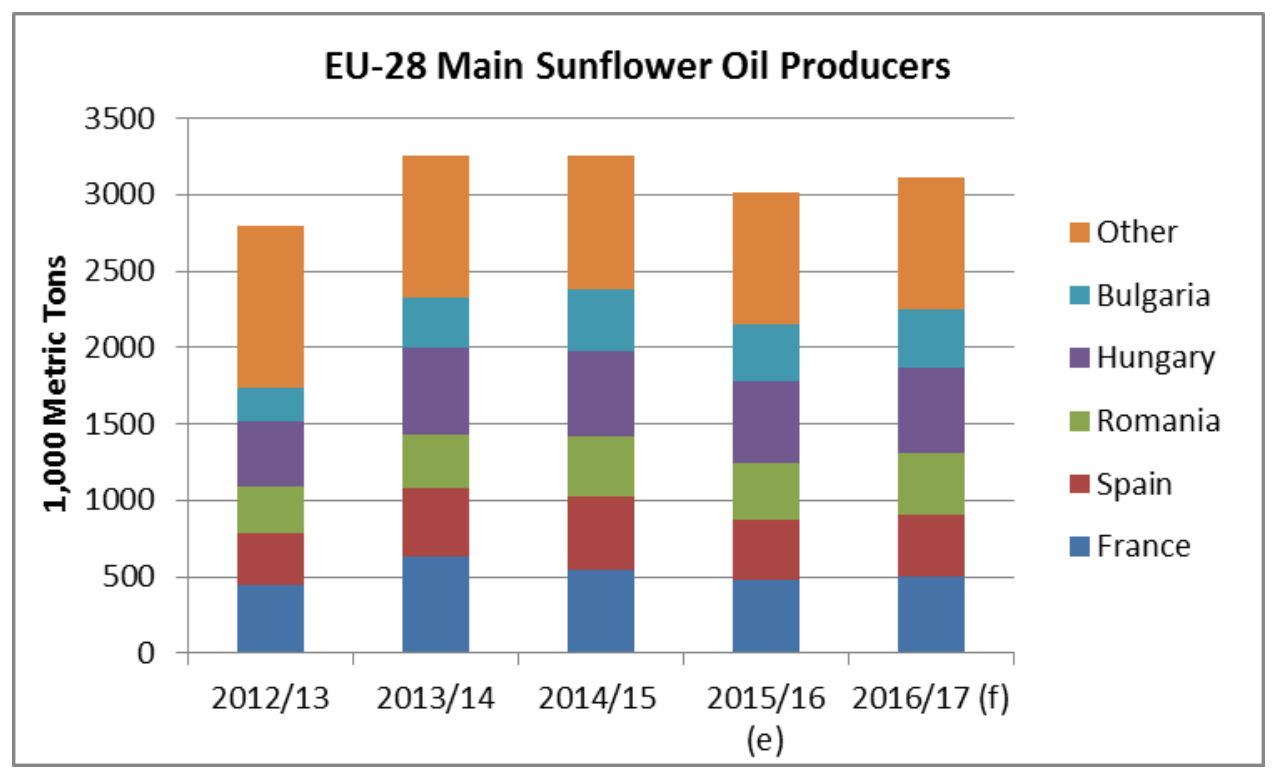

Source: FAS EU-28

\section{MY 2015/16}

Sunflower oil output has declined across the EU by 8 percent due to lower crush. Imports are expected to increase substantially by 28 percent to meet favorable food use demand. Abundant and price-competitive supplies in the Black Sea and Argentina also facilitate higher imports, especially with the devaluation of exporters' currencies against the Euro. In the first quarter of MY 2015/16, imports grew by 48 percent. Following a decline of 25 percent in exports in the first quarter of the marketing year exports, annual exports are projected to decline by 16 percent due to lower supply and tight regional competition in the Black Sea.

\section{MY 2014/15}

Marginal adjustments were made to oil production and stocks reflecting final higher crush use.

\section{Breakout of EU-28 Industrial Uses for Sunflower Oil in 1000 MT}

\begin{tabular}{|c|c|c|c|}
\hline & MY 2014/15 & MY 2015/16 & MY 2016/17 \\
\hline Biofuels Use & 240 & 230 & 230 \\
\hline Other Industrial Uses & 0 & 0 & 0 \\
\hline Total Industrial Use & 240 & 230 & 230 \\
\hline
\end{tabular}

Source: FAS EU-28 
5. Palm Kernel Complex

Coordinator: Bob Flach, FAS/The Hague

Palm Kernel Meal

\begin{tabular}{|c|c|c|c|c|c|c|}
\hline \multirow{3}{*}{$\begin{array}{l}\text { Meal, Palm Kernel } \\
\text { Market Begin Year } \\
\text { European Union }\end{array}$} & \multicolumn{2}{|c|}{$2014 / 2015$} & \multicolumn{2}{|c|}{ 2015/2016 } & \multicolumn{2}{|c|}{$2016 / 2017$} \\
\hline & \multicolumn{2}{|c|}{ Jan 2015} & \multicolumn{2}{|c|}{ Jan 2016} & \multicolumn{2}{|c|}{ Jan 2017} \\
\hline & USDA Official & New Post & USDA Official & New Post & USDA Official & New Pos \\
\hline Crush & 1 & 0 & 0 & 0 & 0 & 0 \\
\hline Extr. Rate, 999.9999 & 0 & 0 & 0 & 0 & 0 & 0 \\
\hline Beginning Stocks & 0 & 0 & 0 & 0 & 0 & 0 \\
\hline Production & 0 & 0 & 0 & 0 & 0 & 0 \\
\hline MY Imports & 2184 & 2184 & 2100 & 2100 & 0 & 2100 \\
\hline MY Imp. from U.S. & 0 & 0 & 0 & 0 & 0 & 0 \\
\hline Total Supply & 2184 & 2184 & 2100 & 2100 & 0 & 2100 \\
\hline MY Exports & 0 & 0 & 0 & 0 & 0 & 0 \\
\hline Industrial Dom. Cons. & 500 & 500 & 500 & 500 & 0 & 500 \\
\hline Food Use Dom. Cons. & 0 & 0 & 0 & 0 & 0 & 0 \\
\hline Feed Waste Dom. Cons. & 1684 & 1684 & 1600 & 1600 & 0 & 1600 \\
\hline Total Dom. Cons. & 2184 & 2184 & 2100 & 2100 & 0 & 2100 \\
\hline Ending Stocks & 0 & 0 & 0 & 0 & 0 & 0 \\
\hline Total Distribution & 2184 & 2184 & 2100 & 2100 & 0 & 2100 \\
\hline
\end{tabular}

Source: FAS EU-28

\section{Palm Kernel Oil}

\begin{tabular}{|c|c|c|c|c|c|c|}
\hline \multirow{3}{*}{$\begin{array}{l}\text { Oil, Palm Kernel } \\
\text { Market Begin Year } \\
\text { European Union }\end{array}$} & \multicolumn{2}{|c|}{$2014 / 2015$} & \multicolumn{2}{|c|}{$2015 / 2016$} & \multicolumn{2}{|c|}{ 2016/2017 } \\
\hline & \multicolumn{2}{|c|}{ Jan 2015} & \multicolumn{2}{|c|}{ Jan 2016} & \multicolumn{2}{|c|}{ Jan 2017} \\
\hline & USDA Official & New Post & USDA Official & New Post & USDA Official & New Post \\
\hline Crush & 1 & 0 & 0 & 0 & 0 & 0 \\
\hline Extr. Rate, 999.9999 & 0 & 0 & 0 & 0 & 0 & 0 \\
\hline Beginning Stocks & 98 & 98 & 96 & 59 & 0 & 43 \\
\hline Production & 0 & 0 & 0 & 0 & 0 & 0 \\
\hline MY Imports & 617 & 617 & 580 & 600 & 0 & 600 \\
\hline MY Imp. from U.S. & 0 & 0 & 0 & 0 & 0 & 0 \\
\hline Total Supply & 715 & 715 & 676 & 659 & 0 & 643 \\
\hline MY Exports & 4 & 4 & 5 & 4 & 0 & 4 \\
\hline Industrial Dom. Cons. & 200 & 240 & 180 & 220 & 0 & 220 \\
\hline Food Use Dom. Cons. & 400 & 400 & 400 & 380 & 0 & 380 \\
\hline Feed Waste Dom. Cons. & 15 & 12 & 10 & 12 & 0 & 12 \\
\hline Total Dom. Cons. & 615 & 652 & 590 & 612 & 0 & 612 \\
\hline Ending Stocks & 96 & 59 & 81 & 43 & 0 & 27 \\
\hline Total Distribution & 715 & 715 & 676 & 659 & 0 & 643 \\
\hline
\end{tabular}

Source: FAS EU-28

In 2016 and 2017, EU palm kernel meal use for feed is expected to decline slightly to about 1.60 million metric tons from 1.67 million metric tons in 2015. This reduction is a result of the stagnating supply in Asia in combination with the higher supply of other feed ingredients, mainly soybean derivatives. About half of the palm kernel meal is used in the Benelux countries, predominantly as an ingredient in cattle feed. During the past five years, the use in cattle feed has been about twenty-five percent. Germany, the UK and Ireland also use palm kernel meal in livestock feed. 


\section{Palm Oil}

Coordinator: Bob Flach, FAS/The Hague

\section{Palm Oil}

\begin{tabular}{|c|c|c|c|c|c|c|}
\hline \multirow{3}{*}{\begin{tabular}{|l} 
Oil, Palm \\
Market Begin Year \\
European Union
\end{tabular}} & \multirow{2}{*}{\multicolumn{2}{|c|}{$\begin{array}{c}2014 / 2015 \\
\operatorname{Jan} 2015\end{array}$}} & \multirow{2}{*}{\multicolumn{2}{|c|}{$\begin{array}{c}2015 / 2016 \\
\text { Jan } 2016\end{array}$}} & \multirow{2}{*}{\multicolumn{2}{|c|}{$\begin{array}{c}2016 / 2017 \\
\text { Jan } 2017\end{array}$}} \\
\hline & & & & & & \\
\hline & USDA Official & New Post & USDA Official & New Post & USDA Official & New Post \\
\hline Area Planted & 0 & 0 & 0 & 0 & 0 & 0 \\
\hline Area Harvested & 0 & 0 & 0 & 0 & 0 & 0 \\
\hline Trees & 0 & 0 & 0 & 0 & 0 & 0 \\
\hline Beginning Stocks & 404 & 404 & 358 & 308 & 0 & 298 \\
\hline Production & 0 & 0 & 0 & 0 & 0 & 0 \\
\hline MY Imports & 6770 & 6770 & 6950 & 6700 & 0 & 6650 \\
\hline MY Imp. from U.S. & 0 & 0 & 0 & 0 & 0 & 0 \\
\hline Total Supply & 7174 & 7174 & 7308 & 7008 & 0 & 6948 \\
\hline MY Exports & 116 & 116 & 160 & 100 & 0 & 100 \\
\hline Industrial Dom. Cons. & 3450 & 3200 & 3500 & 3100 & 0 & 3050 \\
\hline Food Use Dom. Cons. & 3000 & 3250 & 3100 & 3230 & 0 & 3230 \\
\hline Feed Waste Dom. Cons. & 250 & 300 & 250 & 280 & 0 & 280 \\
\hline Total Dom. Cons. & 6700 & 6750 & 6850 & 6610 & 0 & 6560 \\
\hline Ending Stocks & 358 & 308 & 298 & 298 & 0 & 288 \\
\hline Total Distribution & 7174 & 7174 & 7308 & 7008 & 0 & 6948 \\
\hline
\end{tabular}

Source: FAS EU-28

Recent official trade figures report a reduction of EU palm oil imports by 200,000 metric tons in 2015 . Reductions are reported for the Netherlands, Italy and Spain, while German palm oil imports increased.

EU imports of crude palm oil increased by nearly 500,000 metric tons, while imports of refined palm oil declined by nearly 700,000 metric tons. In 2016 and 2017, EU imports are forecast to further decline due to the tightening supply from Asia. As a result of its increased availability, soybean oil is expected to replace palm oil in both biofuels and feed rations. Due to the physical characteristics and non GM content, the replacement of palm oil in food preparations is expected to be limited. However, negative NGO campaigns about the environmental impact of palm oil production potentially hinder the further penetration in the food sector. Based on environmental considerations, the French Government proposed to impose an additional tax for food grade palm oil of 90 euro per metric ton as from 2017.

EU palm oil use for industrial purposes, including for generation of power and heat, and production of biofuels, is estimated at about 3.2 million metric tons in 2015. For 2015, the use of palm oil for biofuel production is estimated at 1.5 million metric tons. The use for biofuel production is expected to decline to about 1.4 and 1.35 million metric tons in 2016 and 2017, respectively. The HVO (hydrotreated vegetable oils) plant in Rotterdam has reached its full capacity, and is gradually replacing palm oil with waste fats and oils. The company's goal is to use only waste oils and fats as feedstock as from 2017. Another factor for the lower industrial use is the low fossil fuel prices which is curtailing the use of palm oil for power and heat generation. Spain is expected to continue to use significant volumes of palm oil for biodiesel and HVO production. The higher iodine number permitted in Spain allows for an intensive use of soybean and palm oil in biodiesel production for domestic consumption. According to our estimates, palm oil could make up for over 50 percent of the raw materials used in domestically produced biodiesel.

If palm oil is used for the production of biofuels it must be certified as sustainable as laid down on the Renewable Energy Directive (RED). The European Commission approved the Roundtable on Sustainable Palm Oil (RSPO) program as compliant with the RED as from December 14, 2012, for a period of five years. Sustainability certification is also an important factor for acceptance in the food market. In the EU, the sectors in the Netherlands, the United Kingdom and Belgium set the goal of using palm oil certified by the Roundtable on Sustainable Palm Oil (RSPO) or equivalent by the end of 2015. Final market figures are not yet public, but reportedly the sales of certified palm oil are close to reaching these goals. In 2014, the Dutch and the UK sector 
reported both an equal share of 72 percent of certified palm oil on total domestic consumption. In 2015 , the production of RSPO certified palm oil reached 13.5 million metric tons, which is about 21 percent of the annual global production.

\section{Breakout of EU-28 Industrial Uses for Palm Oil in 1000 MT}

\begin{tabular}{|c|c|c|c|}
\hline & MY 2014/15 & MY 2015/16 & MY 2016/17 \\
\hline Biofuels Use & 1,500 & 1,400 & 1,350 \\
\hline Other Industrial Uses & 1,700 & 1,700 & 1,700 \\
\hline Total Industrial Use & 3,200 & 3,100 & 3,050 \\
\hline
\end{tabular}

Source: FAS EU-28

\section{Peanut Complex}

Coordinator Jennifer Wilson, FAS/London

\section{Peanuts}

\begin{tabular}{|c|c|c|c|c|c|c|}
\hline \multirow{3}{*}{$\begin{array}{l}\text { Oilseed, Peanut } \\
\text { Market Begin Year } \\
\text { European Union }\end{array}$} & \multicolumn{2}{|c|}{ 2014/2015 } & \multicolumn{2}{|c|}{ 2015/2016 } & \multicolumn{2}{|c|}{$2016 / 2017$} \\
\hline & \multicolumn{2}{|c|}{\begin{tabular}{|l|} 
Oct 2014 \\
\end{tabular}} & \multicolumn{2}{|c|}{ Oct 2015} & \multicolumn{2}{|c|}{ Oct 2016} \\
\hline & USDA Official & New Post & USDA Official & New Post & USDA Official & New Post \\
\hline Area Planted & 0 & 0 & 0 & 0 & 0 & 0 \\
\hline Area Harvested & 0 & 0 & 0 & 0 & 0 & 0 \\
\hline Beginning Stocks & 18 & 18 & 18 & 18 & 0 & 18 \\
\hline Production & 0 & 0 & 0 & 0 & 0 & 0 \\
\hline MY Imports & 814 & 822 & 825 & 825 & 0 & 830 \\
\hline MY Imp. from U.S. & 190 & 136 & 200 & 180 & 0 & 190 \\
\hline Total Supply & 832 & 840 & 843 & 843 & 0 & 848 \\
\hline MY Exports & 31 & 28 & 25 & 30 & 0 & 30 \\
\hline Crush & 32 & 35 & 32 & 35 & 0 & 35 \\
\hline Food Use Dom. Cons. & 748 & 756 & 765 & 757 & 0 & 760 \\
\hline Feed Waste Dom. Cons. & 3 & 3 & 3 & 3 & 0 & 3 \\
\hline Total Dom. Cons. & 783 & 794 & 800 & 795 & 0 & 798 \\
\hline Ending Stocks & 18 & 18 & 18 & 18 & 0 & 20 \\
\hline Total Distribution & 832 & 840 & 843 & 843 & 0 & 848 \\
\hline
\end{tabular}

Source: FAS EU-28

The European Union is the largest importer of peanut and peanut products in the world. Trade in ready-shelled peanuts increased by over ten percent between the marketing years 2005/2006 to 2014/2015. In-shell peanut imports into the EU declined by over thirty-seven percent in the same time period. The latter now comprises only 8 percent of total tonnage. China and the U.S. lead exports of in-shell to the EU, while Argentina dominates the shelled peanut trade. On the back of the U.S. record harvest in 2012 and ample supply through to MY 2015/2016, imports are estimated to increase from the U.S. over the previous marketing year. The majority of shelled peanuts are supplied by Argentina (50-60 percent), and ultimately directed to the EU confectionery market. With a large supply of U.S. peanuts on the global market, Argentina is less likely to increase planting and production. However in MY 2015/16 both key suppliers are likely to have an adequate supply for export, therefore EU import and distribution is expected to slightly increase. Other suppliers include China and increasingly Brazil. In general, U.S. shelled peanut trade with the EU is price-driven but trade is also dependent on the ease with which U.S. suppliers can meet EU requirements for pesticide residues, aflatoxin levels, phytosanitary certificates and private industry standards. After years of consolidation, the EU peanut kernel market is dominated by very few large multi-national processors. 


\section{Peanut Meal}

\begin{tabular}{|c|c|c|c|c|c|c|}
\hline \multirow{3}{*}{$\begin{array}{l}\text { Meal, Peanut } \\
\text { Market Begin Year } \\
\text { European Union }\end{array}$} & \multicolumn{2}{|c|}{$2014 / 2015$} & \multicolumn{2}{|c|}{$2015 / 2016$} & \multicolumn{2}{|c|}{$2016 / 2017$} \\
\hline & \multicolumn{2}{|c|}{\begin{tabular}{|l|} 
Oct 2014 \\
\end{tabular}} & \multicolumn{2}{|c|}{ Oct 2015} & \multicolumn{2}{|c|}{ Oct 2016} \\
\hline & USDA Official & New Post & USDA Official & New Post & USDA Official & New Post \\
\hline Crush & 32 & 35 & 32 & 35 & 0 & 35 \\
\hline Extr. Rate, 999.9999 & 0.4375 & 0.4286 & 0.4375 & 0.4286 & 0 & 0.4286 \\
\hline Beginning Stocks & 0 & 0 & 0 & 0 & 0 & 0 \\
\hline Production & 14 & 15 & 14 & 15 & 0 & 15 \\
\hline MY Imports & 4 & 4 & 7 & 4 & 0 & 4 \\
\hline MY Imp. from U.S. & 0 & 0 & 0 & 0 & 0 & 0 \\
\hline Total Supply & 18 & 19 & 21 & 19 & 0 & 19 \\
\hline MY Exports & 0 & 0 & 0 & 0 & 0 & 0 \\
\hline Industrial Dom. Cons. & 0 & 0 & 0 & 0 & 0 & 0 \\
\hline Food Use Dom. Cons. & 0 & 0 & 0 & 0 & 0 & 0 \\
\hline Feed Waste Dom. Cons. & 18 & 19 & 21 & 19 & 0 & 19 \\
\hline Total Dom. Cons. & 18 & 19 & 21 & 19 & 0 & 19 \\
\hline Ending Stocks & 0 & 0 & 0 & 0 & 0 & 0 \\
\hline Total Distribution & 18 & 19 & 21 & 19 & 0 & 19 \\
\hline
\end{tabular}

\section{Source: FAS EU-28}

Peanuts for confectionery and other further processed product uses remains the focal point for trade. Peanut crushing within the EU has not increased in recent times. The main supplier to the EU of peanut meal is Senegal. Exports from West Africa are erratic and intrinsically linked to political levers, as well as extreme weather events. Reports from FAS/USDA in Senegal indicated that there was likely to be a lack of quality seeds going into 2015 production. This, coupled with unclear government support for Senegalese farmers, resulted in a decrease in peanut meal imports to the EU last marketing year to a very low level and an uncertain outlook for the forecast years.

\section{Peanut Oil}

\begin{tabular}{|c|c|c|c|c|c|c|}
\hline \multirow{3}{*}{\begin{tabular}{|l} 
Oil, Peanut \\
Market Begin Year \\
European Union
\end{tabular}} & \multirow{2}{*}{\multicolumn{2}{|c|}{$2014 / 2015$}} & \multirow{2}{*}{\multicolumn{2}{|c|}{$2015 / 2016$}} & \multicolumn{2}{|c|}{$2016 / 2017$} \\
\hline & & & & Oct 2015 & \multicolumn{2}{|c|}{ Oct 2016} \\
\hline & USDA Official & New Post & USDA Official & New Post & USDA Official & New Post \\
\hline Crush & 32 & 35 & 32 & 35 & 0 & 35 \\
\hline Extr. Rate, 999.9999 & 0.375 & 0.3429 & 0.375 & 0.3429 & 0 & 0.3429 \\
\hline Beginning Stocks & 3 & 3 & 3 & 3 & 0 & 3 \\
\hline Production & 12 & 12 & 12 & 12 & 0 & 12 \\
\hline MY Imports & 73 & 71 & 75 & 70 & 0 & 68 \\
\hline MY Imp. from U.S. & 0 & 0 & 0 & 0 & 0 & 0 \\
\hline Total Supply & 88 & 86 & 90 & 85 & 0 & 83 \\
\hline MY Exports & 4 & 3 & 3 & 3 & 0 & 3 \\
\hline Industrial Dom. Cons. & 0 & 0 & 0 & 0 & 0 & 0 \\
\hline Food Use Dom. Cons. & 81 & 80 & 84 & 79 & 0 & 77 \\
\hline Feed Waste Dom. Cons. & 0 & 0 & 0 & 0 & 0 & 0 \\
\hline Total Dom. Cons. & 81 & 80 & 84 & 79 & 0 & 77 \\
\hline Ending Stocks & 3 & 3 & 3 & 3 & 0 & 3 \\
\hline Total Distribution & 88 & 86 & 90 & 85 & 0 & 83 \\
\hline 1000 MT) ,(PERCENT) & & & & & & \\
\hline
\end{tabular}

\section{Source: FAS EU-28}

Although it undergoes further refinement after crushing, peanut oil must be labelled on EU food packaging as an allergen. This deters its widespread use in food applications. EU peanut oil consumption has declined in the last ten years, and is increasingly substituted by other oils (such as sunflower oil) in Europe. Senegal was the largest 
supplier of peanut oil to the EU in MY 2014/15. Brazil was the leading supplier for the preceding 3 years and other suppliers include Argentina and Nicaragua. Since January 2014, Argentina and Brazil are no longer eligible for preferential access when trading with the EU. This new tariff scenario may bring opportunities to Central American and African countries, such as Senegal, that already play an important role in supply of peanut oil.

\section{Fish Meal}

Coordinator: Bob Flach, FAS/The Hague

Fish Meal

\begin{tabular}{|c|c|c|c|c|c|c|}
\hline \multirow{3}{*}{\begin{tabular}{|l|} 
Meal, Fish \\
Market Begin Year \\
European Union
\end{tabular}} & \multicolumn{2}{|c|}{ 2014/2015 } & \multirow{2}{*}{\multicolumn{2}{|c|}{$\begin{array}{c}2015 / 2016 \\
\operatorname{Jan} 2016\end{array}$}} & \multicolumn{2}{|c|}{ 2016/2017 } \\
\hline & \multicolumn{2}{|c|}{\begin{tabular}{|l|} 
Jan 2015 \\
\end{tabular}} & & & \multicolumn{2}{|c|}{ Jan 2017} \\
\hline & USDA Official & New Post & USDA Official & New Post & USDA Official & New Post \\
\hline Beginning Stocks & 0 & 0 & 0 & 0 & 0 & 0 \\
\hline Production & 455 & 455 & 460 & 460 & 0 & 460 \\
\hline MY Imports & 279 & 279 & 250 & 300 & 0 & 300 \\
\hline MY Imp. from U.S. & 2 & 8 & 0 & 8 & 0 & 8 \\
\hline Total Supply & 734 & 734 & 710 & 760 & 0 & 760 \\
\hline MY Exports & 205 & 205 & 225 & 210 & 0 & 210 \\
\hline Industrial Dom. Cons. & 0 & 0 & 0 & 0 & 0 & 0 \\
\hline Food Use Dom. Cons. & 0 & 0 & 0 & 0 & 0 & 0 \\
\hline Feed Waste Dom. Cons. & 529 & 529 & 485 & 550 & 0 & 550 \\
\hline Total Dom. Cons. & 529 & 529 & 485 & 550 & 0 & 550 \\
\hline Ending Stocks & 0 & 0 & 0 & 0 & 0 & 0 \\
\hline Total Distribution & 734 & 734 & 710 & 760 & 0 & 760 \\
\hline
\end{tabular}

The EU is dependent on fishmeal imports to fulfill domestic demand. In 2015, EU imports and use of fishmeal declined due to lower production in South America and the increased availability of soybean meal. In 2016, imports and use are expected to recover due to higher exportable supplies in South America. Germany and Denmark are the biggest markets for fishmeal in the EU. Together these countries account for about 85 percent of total EU imports. Denmark is also the main fishmeal producer in the EU, with an annual production generally fluctuating between $150,000-200,000$ metric tons. 


\section{Copra Complex}

Coordinator: Leif Erik Rehder, FAS/Berlin

Copra is not produced and no longer processed in the EU-28. The EU-28 satisfies all its copra meal and coconut oil demand with imports.

\section{Copra Meal}

\begin{tabular}{|c|c|c|c|c|c|c|}
\hline \multirow{3}{*}{\begin{tabular}{|l|} 
Meal, Copra \\
Market Begin Year \\
European Union
\end{tabular}} & \multirow{2}{*}{\multicolumn{2}{|c|}{$\begin{array}{c}2014 / 2015 \\
\text { Jan } 2015\end{array}$}} & \multirow{2}{*}{\multicolumn{2}{|c|}{$\begin{array}{c}2015 / 2016 \\
\text { Jan } 2016\end{array}$}} & \multirow{2}{*}{\multicolumn{2}{|c|}{$\begin{array}{c}2016 / 2017 \\
\text { Jan } 2017\end{array}$}} \\
\hline & & & & & & \\
\hline & USDA Official & New Post & USDA Official & New Post & USDA Official & New Post \\
\hline Crush & 0 & 0 & 0 & 0 & 0 & 0 \\
\hline Extr. Rate, 999.9999 & 0 & 0 & 0 & 0 & 0 & 0 \\
\hline Beginning Stocks & 0 & 0 & 0 & 0 & 0 & 0 \\
\hline Production & 0 & 0 & 0 & 0 & 0 & 0 \\
\hline MY Imports & 2 & 3 & 3 & 3 & 0 & 3 \\
\hline MY Imp. from U.S. & 0 & 0 & 0 & 0 & 0 & 0 \\
\hline Total Supply & 2 & 3 & 3 & 3 & 0 & 3 \\
\hline MY Exports & 0 & 0 & 0 & 0 & 0 & 0 \\
\hline Industrial Dom. Cons. & 0 & 0 & 0 & 0 & 0 & 0 \\
\hline Food Use Dom. Cons. & 0 & 0 & 0 & 0 & 0 & 0 \\
\hline Feed Waste Dom. Cons. & 2 & 3 & 3 & 3 & 0 & 3 \\
\hline Total Dom. Cons. & 2 & 3 & 3 & 3 & 0 & 3 \\
\hline Ending Stocks & 0 & 0 & 0 & 0 & 0 & 0 \\
\hline Total Distribution & 2 & 3 & 3 & 3 & 0 & 3 \\
\hline (1000 MT), (PERCENT) & & & & & & \\
\hline
\end{tabular}

\section{Source: FAS EU-28}

Imports of copra meal have dropped significantly with India as the only significant supplier. Imports of copra meal are expected to remain flat at 3,000 $t$ in 2015, 2016 and 2017.

\section{Coconut Oil}

\begin{tabular}{|c|c|c|c|c|c|c|}
\hline \multirow{3}{*}{$\begin{array}{l}\text { Oil, Coconut } \\
\text { Market Begin Year } \\
\text { European Union }\end{array}$} & \multicolumn{2}{|c|}{$2014 / 2015$} & \multicolumn{2}{|c|}{$2015 / 2016$} & \multicolumn{2}{|c|}{$2016 / 2017$} \\
\hline & \multicolumn{2}{|c|}{\begin{tabular}{|l|} 
Jan 2015 \\
\end{tabular}} & \multicolumn{2}{|c|}{ Jan 2016} & \multicolumn{2}{|c|}{ Jan 2017} \\
\hline & USDA Official & New Post & USDA Official & New Post & USDA Official & New Post \\
\hline Crush & 0 & 0 & 0 & 0 & 0 & 0 \\
\hline Extr. Rate, 999.9999 & 0 & 0 & 0 & 0 & 0 & 0 \\
\hline Beginning Stocks & 34 & 34 & 34 & 34 & 0 & 31 \\
\hline Production & 0 & 0 & 0 & 0 & 0 & 0 \\
\hline MY Imports & 543 & 543 & 550 & 520 & 0 & 520 \\
\hline MY Imp. from U.S. & 0 & 0 & 0 & 0 & 0 & 0 \\
\hline Total Supply & 577 & 577 & 584 & 554 & 0 & 551 \\
\hline MY Exports & 8 & 8 & 0 & 8 & 0 & 8 \\
\hline Industrial Dom. Cons. & 210 & 210 & 210 & 200 & 0 & 200 \\
\hline Food Use Dom. Cons. & 320 & 315 & 335 & 305 & 0 & 305 \\
\hline Feed Waste Dom. Cons. & 5 & 10 & 5 & 10 & 0 & 10 \\
\hline Total Dom. Cons. & 535 & 535 & 550 & 515 & 0 & 515 \\
\hline Ending Stocks & 34 & 34 & 34 & 31 & 0 & 28 \\
\hline Total Distribution & 577 & 577 & 584 & 554 & 0 & 551 \\
\hline$(1000 \mathrm{MT}),($ PERCENT) & & & & & & \\
\hline
\end{tabular}

\section{Source: FAS EU-28}

In 2015 EU imports of coconut oil have decreased to 543,000 t. Imports of coconut oil are expected to decrease further in 2016 due to high prices and lower production in the Philippines. 


\title{
10. Cottonseed
}

\author{
Coordinator: Dimosthenis Faniadis, FAS/Rome
}

Please note that due to changed reporting requirements only cottonseed is included in this report. Previous reports also included cottonseed meal and cottonseed oil.

\section{Cottonseed}

\begin{tabular}{|c|c|c|c|c|c|c|}
\hline \multirow{3}{*}{$\begin{array}{l}\text { Oilseed, Cottonseed } \\
\text { Market Begin Year } \\
\text { European Union }\end{array}$} & \multicolumn{2}{|c|}{$2014 / 2015$} & \multicolumn{2}{|c|}{$2015 / 2016$} & \multicolumn{2}{|c|}{$2016 / 2017$} \\
\hline & \multicolumn{2}{|c|}{\begin{tabular}{|l|} 
Oct 2014 \\
\end{tabular}} & \multicolumn{2}{|c|}{ Oct 2015} & \multicolumn{2}{|c|}{ Oct 2016} \\
\hline & USDA Official & New post & USDA Official & New post & USDA Official & New pos \\
\hline Area Planted (Cotton) & 360 & 0 & 330 & 0 & 0 & 0 \\
\hline Area Harvested (Cotton) & 355 & 353 & 315 & 308 & 0 & 285 \\
\hline Beginning Stocks & 89 & 89 & 69 & 67 & 0 & 42 \\
\hline Production & 523 & 519 & 383 & 428 & 0 & 402 \\
\hline MY Imports & 12 & 12 & 30 & 30 & 0 & 45 \\
\hline Total Supply & 624 & 620 & 482 & 525 & 0 & 489 \\
\hline MY Exports & 45 & 45 & 50 & 50 & 0 & 40 \\
\hline Crush & 330 & 329 & 280 & 281 & 0 & 266 \\
\hline Food Use Dom. Cons. & 0 & 2 & 0 & 2 & 0 & 2 \\
\hline Feed Waste Dom. Cons. & 180 & 177 & 130 & 150 & 0 & 143 \\
\hline Total Dom. Cons. & 510 & 508 & 410 & 433 & 0 & 411 \\
\hline Ending Stocks & 69 & 67 & 22 & 42 & 0 & 38 \\
\hline Total Distribution & 624 & 620 & 482 & 525 & 0 & 489 \\
\hline
\end{tabular}

Source: FAS EU-28

\section{Production}

The EU-28 is a minor producer of cotton. EU-28 cotton production has declined by more than 50 percent following Common Agricultural Policy (CAP) reforms effective in 2006 that decoupled payments and reduced support and market barriers for a number of crops, including cotton. The EU-28 does not permit farmers to cultivate modern biotech cotton varieties, further hurting competitiveness. Only two EU-28 Members States, Greece (80 percent) and Spain (20 percent) grow significant amounts of cotton commercially. Cotton is a major agricultural crop in Greece, accounting for more than 8 percent of total agricultural output. More than 50,000 farmers grow cotton, producing about 80 percent of the EU crop. Thessaly, Macedonia, Thrace and mainland Greece are the major cotton-producing areas. Cotton is planted from March 1 to April 15; the crop life cycle is usually 170 to 210 days, depending on the variety and weather conditions. The harvest occurs from October 1 to November 30 and most of the cotton is machine harvested. Spain's cotton area is concentrated in the region of Andalusia, and it is progressively concentrating in the provinces of Seville and Cadiz. Cotton is grown on some of the best agricultural land, competing with other irrigated crops. Greece's MY 2016/17 cottonseed production is forecast to decrease 6 percent compared to the previous year. Spain's MY 2016/17 is forecast to be similar to the previous MY. Yields in both Greece and Spain are expected to be average.

\section{Crush}

In Greece, about 55 percent of cottonseed production is crushed for oil (and oilseed cake) or retained for seed. In Spain, there is no domestic crushing of cottonseed.

\section{Trade}

Despite Greece used to be a major cottonseed exporter, the last years cottonseed exports are decreasing and are forecasted to further decrease. The EU-28 cottonseed exports decreased 21.5 percent comparing to the previous year. In Greece, small amounts of cotton are imported for blending in the domestic spinning industry. Spanish cottonseed domestic demand is also satisfied by imports. 


\section{Olive Oil}

\section{Coordinator: Marta Guerrero, FAS/Madrid}

\section{Olive Oil}

\begin{tabular}{|c|c|c|c|c|c|c|}
\hline \multirow{3}{*}{$\begin{array}{l}\text { Oil, Olive } \\
\text { Market Begin Year } \\
\text { European Union }\end{array}$} & \multirow{2}{*}{\multicolumn{2}{|c|}{$\begin{array}{c}2014 / 2015 \\
\text { Nov } 2014\end{array}$}} & \multirow{2}{*}{\multicolumn{2}{|c|}{$\begin{array}{c}2015 / 2016 \\
\text { Nov } 2015\end{array}$}} & \multirow{2}{*}{\multicolumn{2}{|c|}{$\begin{array}{c}2016 / 2017 \\
\text { Nov } 2016\end{array}$}} \\
\hline & & & & & & \\
\hline & USDA Official & New post & USDA Official & New post & USDA Official & New post \\
\hline Area Planted & 0 & 0 & 0 & 0 & 0 & 0 \\
\hline Area Harvested & 0 & 0 & 0 & 0 & 0 & 0 \\
\hline Trees & 6,750 & 0 & 6,750 & 0 & 0 & 0 \\
\hline Beginning Stocks & 431 & 431 & 99 & 100 & 0 & 230 \\
\hline Production & 1,550 & 1,435 & 2,100 & 2,075 & 0 & 2,120 \\
\hline MY Imports & 253 & 236 & 130 & 175 & 0 & 175 \\
\hline MY Imp. from U.S. & 0 & 0 & 0 & 0 & 0 & 0 \\
\hline Total Supply & 2,234 & 2,102 & 2,329 & 2,350 & 0 & 2,535 \\
\hline MY Exports & 565 & 492 & 600 & 600 & 0 & 625 \\
\hline Industrial Dom. Cons. & 20 & 20 & 20 & 20 & 0 & 20 \\
\hline Food Use Dom. Cons. & 1,550 & 1,490 & 1,630 & 1,500 & 0 & 1,560 \\
\hline Feed Waste Dom. Cons. & 0 & 0 & 0 & 0 & 0 & 0 \\
\hline Total Dom. Cons. & 1,570 & 1,410 & 1,650 & 1,520 & 0 & 1,580 \\
\hline Ending Stocks & 99 & 100 & 79 & 230 & 0 & 320 \\
\hline Total Distribution & 2,234 & 2,102 & 2,329 & 2,350 & 0 & 2,535 \\
\hline
\end{tabular}

\section{Source: FAS EU-28}

\section{MY 2016/17}

Rough estimates indicate similar olive oil production levels in the EU-28 for MY 2016/17 to those achieved in MY 2015/16, based on stable yields in Spain and production rebound in Italy and Greece. Average yields are projected for the other European producing countries. Two years of average harvests in a row would allow for stocks to replenish and continue the steady pace of export growth.

\section{MY 2015/16}

\section{Production}

Olive oil production in the EU is fairly concentrated in the Mediterranean area. Spain, followed by Italy, Greece and Portugal, are the main olive oil producers in the European Union. Olive oil production also exists in other European countries such as Cyprus, France, Croatia and Slovenia.

After plummeting in MY 2014/15 due to unfavorable weather conditions in Spain and Portugal, a production recovery was registered in MY 2015/16.

In Spain, the world largest olive oil producing country, olive oil production is anticipated to reach 1.35 million MT in MY 2015/16, up from previous season levels. Dry conditions and warmer than normal temperatures during blooming and fruit setting prevented from achieving record yields.

Olive oil production in Portugal is anticipated to be one of the largest recorded as a consequence of restructuration, investments in irrigation and favorable weather conditions.

According to the latest industry estimates, in Italy, MY 2015/16 olive oil production is forecast to rebound to 350,000 MT from the 222,000 MT obtained in the previous season. MY 2014/15 2014 was as a particularly bad 
year for Italian olive oil producers with groves enduring adverse weather, a fruit-fly blight, and a bacterial disease dubbed "olive tree leprosy" (Xylella fastidiosa). Many of Italy's oldest olive tree groves, some 500 years old, have been infected by the bacteria, causing plants to dry out, leaving shriveled stumps that are incapable of bearing fruit. In MY 2015/16 a rainy spring and a warm and dry summer contributed to reduced olive disease.

Greece's MY 2015/16 olive oil production is forecast to remain close to the previous year's campaign, at 295,000 Metric Tons (MT), thanks to very good yields in the South of Greece (Peloponnese), particularly in prefectures of Messina and llia.

\section{Consumption}

Ample domestic supplies are anticipated to result in a tepid consumption recovery in the European Union, both in main olive oil producing member states are who also main consuming member states, but also in non-producing member states.

\section{Trade}

In MY 2014/15, despite the poor domestic crop in, EU exporters managed to keep high levels of exports. EU exporters will continue being determined to meet export commitments in third markets in MY 201516. As a result of the shorter domestic supply and the steady pace of exports, MY 2015/16 began with historically low levels of stocks. Despite the more ample domestic supply of olive oil in MY 2015/16, significant imports are still forecasted, the large majority of them originated in Tunisia.

\section{Policy}

A Commission Implementing Regulation amending Regulation (EC) 1918/2006 is pending from final approval by the Council of Ministers and publication in the European Union Official Gazette, as it already passed an EU parliament plenary voting on February 25, 2016.

This piece of regulation would open a two-year additional of tariff quota for olive oil originating in Tunisia. In particular, the EC will grant Tunisia with an annual quota of 35,000 MT of olive oil duty free to the EU until the end of 2017, in addition to the 56,700 MT referred to in the Association Agreement between the two parties.

The new Tunis olive oil TRQ would be enforced retroactively since January 1, 2016. It will not encourage additional imports as the EU will discount duties on the olive oil that Tunisia has already been exported to the EU.

\section{Policy}

Coordinator: Barrie Williams, FAS/USEU Brussels

\section{The Common Agriculture Policy}

The new Common Agriculture Policy (CAP) entered into force in January 2014, with the exception of the new direct payments structure, including "green" payments, and additional support for young farmers, which applied from 2015. 
One significant change is the "greening component" in Pillar 1, where the Commission provides that there should be three elements of greening that all farmers would have to comply with to receive direct payments. These three components are:

- Crop Diversification - Farmers must produce at least three different crops, each one accounting for a maximum of 70 percent and a minimum of five percent of each farm.

- Conservation of permanent grassland - With environmentally sensitive grassland, farmers may not convert permanent grassland into another crop. The EU defines permanent grassland as grass that has been there for five years. For permanent grassland in general, farmers can convert but have to reconvert where the ratio of permanent grassland to agricultural land decreases too much in a region or Member State (MS).

- Ecological focus areas (EFA) - Farmers must reserve at least five percent of arable area for ecological use, i.e. field margins, hedges, trees, fallow land, landscape features, biotopes, buffer strips, afforested area. Subject to a Commission report, this area may increase to seven percent after 2017. One option for EFAs is to have nitrogen-fixing crops, e.g. protein crops. It is up to each MS to decide whether to use this option or not.

For more information on the new CAP see: http://www.usda-eu.org/topics/cap-reform/

\section{Aid System for Oilseeds}

Farmers do not receive specific payment for growing oilseeds. The impact of the elimination of production-linked subsidies on the EU oilseeds market is marginal compared to the impact of the growing biofuels market.

The high demand for rapeseed for the production of biofuels due to the introduction of the Renewable Energy Directive (RED) in 2009 led to increased prices which were enough of an incentive for farmers to increase rapeseed production over the last few years.

With the exception of the olive sector, there is no intervention buying, export subsidy or other market support programs available for oilseeds in the EU. The Commission can provide private storage aid (PSA) if there are serious disturbances to the olive oil market in a certain region or the average price for one or more of the following products are recorded on the market during a two weeks period:

$\bullet € 1,779 /$ ton for extra virgin olive oil

$\bullet € 1,710 /$ ton for virgin olive oil

$\bullet € 1,524 /$ ton for lampante olive oil

\section{Protein Deficiency}

EU protein crop production provides only about 30 percent of the protein consumed as animal feed in the EU. The remaining 70 percent of the protein crops are imported, mainly as soy proteins. Imports are estimated to represent the equivalent of 20 million hectares cultivated outside the EU, or more than 10 percent of EU arable land. Only around three percent of EU arable land is currently cultivated with protein crops. However, there are some initiatives to increase the production of protein crops.

In the new CAP, the Commission gives MS the opportunity to support the production of protein crops with up to two percent of their national envelopes. Should any MS decide to use this possibility, the Commission has to be notified in advance. MS must have notified the Commission by August 2014 to benefit from this option from January 1, 2015. Similarly, if the MS wanted to use the coupled option from January 1, 2016, the Commission must have been notified by August 2015.

MS may grant a greater proportion (generally 8 percent but up to 13 percent in some MS, or above 13 percent subject to Commission approval) of their direct payment envelopes in the form of voluntary coupled support (VCS) to farmers in sectors or regions which face particular difficulties and where farming activity is important for economic, environmental and/or social reasons. This aid should be granted only to the extent necessary to maintain current levels of production in the region concerned. An optional additional aid of up to 2 percent of the 
national ceiling is available for MS which decide to use at least 2 percent of the direct payments envelope to support production of protein crops.

There is also an ongoing project on increasing the soy production in the Danube area. The Danube Soya Declaration project has attracted a lot of interest, but so far there has not been a lot of action.

\section{Blair House Agreement}

The 1992 Blair House Memorandum of Understanding on Oilseeds (or Blair House Agreement (BHA)) between the United States and the EU was included in the EU WTO schedule of commitments and resolved a GATT dispute over EU domestic support programs that impaired U.S. access to the EU oilseeds market.

The BHA limited the EU oilseed planting area of mainly rapeseed, sunflower seed, and soybeans, for food and feed purposes to an adjusted maximum guaranteed area (MGA) for those producers benefiting from crop specific oilseed payments. This resulted in a reduction of the EU oilseed production area and penalized production in excess of the maximum.

The BHA also limited the production of oilseeds not intended for human or animal consumption planted on setaside land ("non-food" set-aside). Output of these oilseeds was limited to 1 MMT of byproducts expressed in soybean meal equivalent annually. As the set-aside arrangements are no longer applicable in the CAP, the "nonfood" set-aside scheme is similarly not applicable.

The BHA is triggered by crop specific payments. With the elimination of the crop specific payments, the BHA is maintained as a mechanism but is not used. However, if the introduction of VCS on oilseeds were to trigger the $\mathrm{BHA}$, the Commission asserts that measures are in place to ensure that the MGA is not overshot.

\section{Sustainability}

As in the United States, the interest for sustainability, sustainable production, and environmental issues are growing among EU consumers, industry and policymakers, impacting policy in several areas. The theme of sustainability is well established in the EU marketplace and major food retailers in the EU are increasingly using it as a competitive tool. It is a formal part of retailer business and marketing plans and it is being reinforced by significant investment throughout the production chain, including the growing use of private certification bodies.

Within the European Commission, DG Agriculture and DG Environment are focusing on resource issues such as carbon, water, and biodiversity. Sustainable production is defined as an agricultural sector which is able to maintain viable production throughout the territory of the EU, and which at the same time contributes to the EU's key environmental goals, including the protection of natural and cultural resources and the achievement of successful climate change mitigation and adaptation.

The Commission co-chairs the European Food Sustainable Consumption and Production Round Table, which began as an industry initiative. The objective of this roundtable is to help consumers and other stakeholders to make informed choices by providing them with accurate and understandable information on relevant product characteristics, including environmental performance. This is done by the development of a common framework facilitating environmental assessments. 


\section{EU Climate and Energy Package}

The EU Energy and Climate Change Package (CCP) was adopted by the European Council on April 6, 2009. The Renewable Energy Directive (RED), which is part of this package, entered into force on June 25, 2009, and had to be transposed into national legislation in the Member States (MS) by December 5, 2010. MS were also required to submit National Renewable Energy Action Plans (NREAP) by June 30, 2010. The adoption and requirement for the implementation of the Directive did not give enough time for either the MS or the Commission to prepare for the implementation.

The EU Energy and Climate Change Package include the "20/20/20" goals for 2020:

- A 20 percent reduction in greenhouse gas (GHG) emissions compared to 1990.

- A 20 percent improvement in energy efficiency compared to forecasts for 2020.

- A 20 percent share for renewable energy in the EU total energy mix. Part of this 20 percent share is a 10 percent minimum target for renewable energy consumed in transport to be achieved by all MS.

The goal for 20 percent renewable energy in total energy consumption is an overall EU goal. The RED then sets different targets for different MS within this overall target, based on each MS' capacity. Therefore, some MS will have to reach much higher targets than the 20 percent, whereas other MS will have much lower targets. In contrast to the 20 percent overall EU target, the 10 percent target for renewable energy in transport is obligatory for all MS. The Commission thought that a 10 percent target in transport for all MS would alleviate concerns referred to in the European Climate Change Program (CCP) that the transport sector is projected to account for most of the growth in energy consumption and thus requires more discipline.

One area that was not included in the RED was the effect that the production of biofuel feedstock has on land use, commonly referred to as indirect land use change (ILUC). ILUC implies that when biofuels are produced on existing agricultural land, the demand for food and feed crops remains, and may lead to someone producing more food and feed somewhere else. The Fuel Quality Directive (FQD) complements the RED and mirrors some of the RED's content such as the sustainability criteria. A key requirement of the FQD is that all fuel suppliers (oil companies) must meet a 6 percent cut in GHG emissions by 2020 across all fuel categories supplied to the market. This is designed to be consistent with the 10 percent use of biofuels and would tend to move demand towards biofuels with higher GHG savings. In addition, the FQD limits ethanol blends to 10 percent or less when ethanol is used as an oxygenate. This creates a blend wall in some MS that potentially risks future growth in ethanol consumption. Fuel specifications for biodiesel place limits on the palm oil and soy oil content of biodiesel.

\section{Biotech}

\section{Asynchronous Rate of Approvals on Soybeans}

The EU livestock industry relies on imports of genetically engineered (GE) feed with soy products being the single largest agriculture import into the European Union (EU). However, the EU's slow approval of GE events restricts U.S. exports. The delay in approvals creates risks for the trade.

Commission Implementing Regulation (EU) No 503/2013 established requirements for applications for GE approvals, such as 90-day feeding trials. U.S. exporters are facing additional burdens. In addition, the risk assessment process is not only based on scientific rationale, but also on compliance with the law as the requirements are legally binding. Even more important is the fact that major problems with the implementation of current EU regulations on GM products are not addressed, specifically the unpredictable and non-transparent nature of the political decision-making process that follows the safety recommendations provided by the European Food Safety Authority (EFSA).

\section{Low Level Presence}

The EU does not have a commercially-viable low level presence policy (LLP). In the fall of 2009, shipments of around 180,000 metric tons of U.S. soy were denied entry into the EU because of the detection of dust from GE corn not yet approved in the EU. As a result of the situation, the EU quickly approved several GE corn products that were stuck in the EU approval process, so that soybean trade could resume. 
In response to this incident, the EU announced a "technical solution" in 2011 in an attempt to minimize trade disruptions due to LLP of unapproved GE events in feed imports. The Regulation, Commission Regulation (EU) No 619/2011 which entered into force on July 20, 2011, permits the inadvertent presence in feed shipments of up to 0.1 percent of a GE product unapproved in the $E U$, if the product is approved in the country of export and it has been three months since EFSA concluded its completeness check.

In effect with this "technical solution", the EU chose not to introduce a commercially-viable policy to address the issue of LLP, but to maintain its zero tolerance position. Although the adoption of the "technical solution" demonstrates that the Commission is aware of the problems caused by asynchronous approvals, the fact that the measure is limited to 0.1 percent renders it commercially unviable.

\section{Pesticides}

The use of three neonicotinoids (clothianidin, imidacloprid and thiametoxam) has been restricted since December 1, 2013 for a period of two years on crops attractive to honeybees such as rapeseed, sunflowers, and soybeans (by Commission Implementing Regulation (EU) No 485/2013). The Commission's action was a response to EFSA's report which identified "high acute risks" for bees by the use of these pesticides. The restrictions applied to seed treatment, soil application (granules) and foliar treatment on bee attractive plants and cereals. This moratorium, which expired in December 2015, is currently being reviewed by the European Food Safety Authority (EFSA). The review is expected to be finished by the end of January 2017. The restrictions on the use of neonicotinoids remain in place while this review is carried out. The European Commission will propose, depending on the outcome of the review and if justified, to further modify the conditions of approval of the three neonicotinoids.

\section{Oilseeds GAIN Reports (EU-28 and Member States since January 2015)}

\section{Olive Harvest Begins with Historically Low Oil Stocks|Oilseeds and Products|Madrid|Spain|11/17/2015}

After plummeting in MY 2014/15, Spain's olive oil production is anticipated to return to average levels in MY $2015 / 16$. The smaller MY2014/15 crop, combined with the steady pace of exports through MY2014/15, lead to the depletion of the olive oil stocks. Hence, should the steady pace of exports continues, the anticipated increased domestic supply will not be sufficient for stock recovery.

Olive Harvest Begins with Historically Low Oil Stocks_Madrid_Spain_11-10-

2015

\section{Oilseeds and Products Market Update|Oilseeds and Products|Sofia|Bulgaria|11/9/2015}

The first tentative post-harvest data on 2015 oilseeds crops showed rapeseed production in line with AgSofia's earlier forecast, however, the sunflower crop declined due to the summer heatwave. Sunflower harvest has been completed at $96 \%$ as of October 30 and production is estimated at 1.7 MMT. Soybean crop had much higher planted area due to new subsidies this year but the lack of farming experience and summer heat/dryness resulted in a low crop, currently estimated by AgSofia at 40,000 MT. ...

Oilseeds and Products Market Update_Sofia_Bulgaria_11-4-

2015

\section{EU-28 Oilseeds Market Update|Oilseeds and Products Grain and Feed Biofuels|Vienna|EU-28|10/30/2015}

This report provides EU-28 production, supply, and demand forecasts for major EU oilseeds, protein meals and related products. EU-28 Oilseeds Market Update_Vienna_EU-28_10-22-

2015

\section{Biofuels Sector Update|Biofuels Grain and Feed Oilseeds and Products|Sofia|Bulgaria|8/26/2015}

The Bulgarian Renewable Energy Act (REA) established a national target of $16 \%$ of renewable energy in total energy consumption and $10 \%$ in transportation fuel consumption by 2020 , and $6 \%$ share in the total reduction of GHG emissions based on sustainability criteria. Biofuel mandates lagged behind the goals and accounted for 5.7\% in 2014. In July 2015, Bulgarian legislators postponed bioethanol mandates for 3 years and the current mandate of $7 \%$ will not be changed until 2018. Biodiesel producers p... 
Biofuels Sector Update_Sofia_Bulgaria_8-13-

2015

\section{Portugal Biofuels Standing Report 2015|Biofuels Oilseeds and Products|Madrid|Portugal|8/13/2015}

The Portuguese biofuels sector faces new challenges since 2015 as biodiesel production quotas have been phased-out and sustainability requirements have been fully enforced. At the same time, new opportunities exist for biofuel producers in the Portuguese market as consumption targets have been moved up from 5.5 to 7.5 percent in terms of energy and a 2.5 percent bioethanol specific-target has been introduced.

Portugal Biofuels Standing Report 2015_Madrid_Portugal_7-27-

2015

Biofuels Market Outlook in Poland 2015|Biofuels Oilseeds and Products|Warsaw|Poland|8/11/2015

In 2014 Poland's total production amounted to 0.7 MMT of biodiesel and 0.14 MMT of bioethanol. For the last few years, imports of bioethanol from other EU countries increased significantly, while local production went down. There is a significant surplus of current domestic production capacity in both biodiesel and bioethanol markets in Poland and further investments in this area are not expected. For the year 2015, the National Indicative Target (NIT) for Poland was set at 7.1 percent. It will ...

Biofuels Market Outlook in Poland 2015_Warsaw_Poland_8-5-

2015

Oilseeds Market Update|Oilseeds and Products Grain and Feed Biofuels|Vienna|EU-28|8/10/2015

This report provides EU-28 production, supply, and demand forecasts for major EU oilseeds, protein meals and related products.

Oilseeds Market Update_Vienna_EU-28_8-5-

2015

Biofuels Annual 2015|Biofuels Oilseeds and Products Grain and Feed Agriculture in the Economy|Prague|Czech Republic|8/4/2015

The Czech Republic implemented the EU legislation and has set targets for greenhouse gas (GHG) savings and for the share of biofuels and renewable electricity in transportation on total consumption. Sufficient production capacities and feedstock should allow meeting of those targets.

Biofuels Annual 2015_Prague_Czech Republic_7-29-

2015

Planting Seed Market in Poland - Outlook 2015|Agricultural Situation Biotechnology - GE Plants and Animals Grain and Feed Oilseeds and Products Planting Seeds|Warsaw|Poland|8/4/2015

Poland is one of the major agricultural plant producers in the EU, with great potential for future planting seed market development. The currant planting seed market value is very low and inadequate for Poland's agricultural productive potential. Sales of certified planting seed show a growing tendency in the last few years, but the dynamics of growth is very slow. Poland is a net importer of planting seeds. In the last five years the average planting seed imports value amounted to U.S. $\$ 210$ mil...

Planting Seed Market in Poland - Outlook 2015_Warsaw_Poland_7-30-

2015

\section{Crop Update|Grain and Feed Oilseeds and Products|Prague|Czech Republic|7/27/2015}

Dry weather with high temperatures resulted in slightly earlier start of grains and rapeseed harvest. Drought causes smaller grains and lower yields. MY2015/16 harvest is forecast to be average, with the sowing area remaining almost unchanged.

Crop Update_Prague_Czech Republic_7-22-2015

Sunflower Market Diversification and Development|Oilseeds and Products Product Brief|Sofia|Bulgaria|7/10/2015

Over the last several years, the Bulgarian oilseeds industry has invested in expanding capacities, diversifying and adding value to some of the major field crops. This trend has been most pronounced with the sunflower crop. While until recently Bulgaria was a net exporter of sunflower seeds, lately the country has increased its crushing capacity. The industry also invested in new processing businesses such as production of bakery sunflower seeds for human consumption. In 2015 Bulgaria may e...

Sunflower Market Diversification and Development_Sofia_Bulgaria_7-6- 
Warm Spring Drives Down Spanish Winter Grains Harvest|Grain and Feed Oilseeds and Products|Madrid|Spain|7/1/2015

Good yields were expected for most of Spain's grain growing regions until early May when high temperatures and lack of precipitation significantly reduced harvest expectations. Spain's central plateau is the area most affected by the hot weather. The winter crop cycle had almost ended when the unusually high temperatures withered the grains in the South. Some Northern grain growing regions can still expect average yields thanks the milder prevailing temperatures and to rain during the first h...

Warm Spring Drives Down Spanish Winter Grains Harvest_Madrid_Spain_6-22-

2015

Position Paper on the Future of Livestock Feeding |Biotechnology - GE Plants and Animals Biotechnology and Other New Production Technologies Oilseeds and Products Agriculture in the News Livestock and Products|Berlin|Germany|6/30/2015

The Federal Association of the German Retail Grocery Trade (BVLH) has adopted a position paper on the feeding of livestock. The paper says that "the vast majority of companies" would support genetically engineered (GE) free protein feed. BVLH represents all food retailers in Germany, Position Paper on the Future of Livestock Feeding _Berlin_Germany_6-52015

\section{Oilseeds and Products Annual 2015|Oilseeds and Products|Prague|Czech Republic|5/4/2015}

Marketing years 2013/14 and 2014/15 were both record breaking: in MY2013/14 rapeseed area in the Czech Republic exceeded the threshold of 400,000 hectares, while in MY2014/15 the yield reaching almost 4 MT/HA resulted in record high rapeseed production of 1.54 million MT. Sunflower production has been declining because of its lowering profitability. Oilseeds and Products Annual 2015_Prague_Czech Republic_4-28-

2015

\section{Weather conditions impact Romanian oilseed crop|Oilseeds and Products|Bucharest|Romania|4/30/2015}

Weather conditions impacted rapeseed planting in the fall of 2014 leading to poor emergence. Excessive moisture contributed further to plant deterioration. Part of the rapeseed area to be replanted will be covered by sunflower seeds MY $2015 / 16$, which was otherwise expected to fall more significantly as a result of low returns last year. The upward trend in the soybean area is boosted by the recent Romanian Government decision to include soybean among the crops eligible for EU couple support. Rom...

Weather conditions impact Romanian oilseed crop_Bucharest_Romania_4-29-

2015

\section{Oilseeds and Products Sector Update|Oilseeds and Products|Sofia|Bulgaria|4/22/2015}

The first tentative official data on 2014 crop production published in late March showed a higher than previously expected area and production of oilseeds in MY2014/15. Based on the new data, total oilseeds area in MY2014/15 is increased by $4 \%$ and total production by $12 \%$. Recent dynamic development of the oilseeds sector outlines key new trends in MY2014/15 and MY2015/16 as follows: Declining rapeseeds area due to lower profitability, the ban on neonicotinoids and current less optimistic pr...

Oilseeds and Products Sector Update_Sofia_Bulgaria_4-17-

2015

Poland - Rapeseed and Products Annual - Spring 2015|Oilseeds and Products Agricultural Situation Biofuels | Warsaw | Poland |4/21/2015

For marketing year (MY) 2015/16, planted area of rapeseed is expected to diminish 2.3 percent in response to declining rapeseed prices as some producers switch to grains. As of the first week of April, the rapeseed crop development was assessed well with good prospects for abundant harvest. Poland's total production of rapeseed for MY 2015/16 is forecast to decline by 7 percent to 3 million metric tons (MMT). FAS Warsaw is forecasting the lower production number than in last (record) 2014 year ...

Poland - Rapeseed and Products Annual - Spring 2015_Warsaw_Poland_4-162015

Select Decreasing Production of Oilseeds, Except for Soybeans|Oilseeds and Products|Vienna|EU-28|4/3/2015 
Total EU-28 oilseeds production for marketing year (MY) 2015/16 is expected to decline by about 9 percent to 32 million metric tons (MMT). Following record yields in MY 2014/15 this is a result of lower and more average yields expectations and partially of reduced acreage. Rapeseed production is forecast to be more than 11 percent lower than in MY 2014/15 and may reach $21.3 \mathrm{MMT}$. Sunflower production is anticipated to be down by 5 percent at 8.5 MMT. Still at a relatively low level but increa...

Oilseeds and Products Annual_Vienna_EU-28_3-31-

2015

\section{French plan for protein crops 2014-2020|Oilseeds and Products|Paris|France|1/7/2015}

In December 2014, the French Minister of Agriculture Stéphane Le Foll released a plan to increase the production of protein crops in France between 2014 and 2020. This plan mainly consists of direct subsidies to farmers that produce protein crops. It is expected to result in an increase in production in the short- to medium-term, which will probably lead to a decrease in soybean imports. However, protein crops are not competitive in France and, if subsidies are removed, production will rever...

French plan for protein crops 2014-2020_Paris_France_1-5-2015

\section{Related GAIN Reports (EU-28 since January 2015)}

\section{Select EU Pork Exports Forecast to Reach a New Record|Livestock and Products|The Hague|EU-28|2/24/2016}

Changes in EU livestock policies led to a surge of beef and pork production in 2015. This year, production is expected to remain high. As the domestic and export market is unable to absorb the additional supply, meat is being stockpiled. These quantities are impacting prices, and will support a further export growth of both beef and pork through 2016.

Livestock and Products Semi-annual_The Hague_EU-28_2-19-

2016

\section{Legal Opinion on New Plant Breeding Techniques (NBTs) to be Publishe|Biotechnology and Other New} Production Technologies|Brussels USEU|EU-28|2/19/2016

The legal analysis carried out by the European Commission (EC) on whether or not certain New Plant Breeding Techniques, known as NBTs, fall under the scope of the European GMO legislation is expected to be published during the first half of 2016. The Commission's legal interpretation will likely impact the use of these technologies in both private and public sectors' efforts to innovate plant breeding in the EU and globally.

Legal Opinion on New Plant Breeding Techniques (NBTs) to be Publishe_Brussels USEU_EU-28_2-16-

2016

\section{EU-28 Oilseeds Market Update|Oilseeds and Products Grain and Feed Biofuels|Vienna|EU-28|10/30/2015}

This report provides EU-28 production, supply, and demand forecasts for major EU oilseeds, protein meals and related products. EU-28 Oilseeds Market Update_Vienna_EU-28_10-22-

2015

\section{Select European Dairy Industry Adjusts to the Post-Quota Realities. |Dairy and Products|Warsaw|EU- $28 \mid 10 / 21 / 2015$}

Despite of the drop of farm-gate milk prices and reduced export demand for cheese and whole dried milk, deliveries of milk in the European Union are expected to increase by 1.1 percent in 2015 and continue to grow into 2016. Increased milk production is expected to be mainly processed into butter and non-fat dried milk, which remain in demand on the world market. In 2015 the European Commission introduced market intervention measures which are expected to help farmers to adjust to the new mark...

Dairy and Products Annual_Warsaw_EU-28_10-16-

2015

19 European countries restrict the cultivation of GE crops |Biotechnology - GE Plants and Animals|Paris|EU$28 \mid 10 / 19 / 2015$

A European Union (EU) directive that allows EU Member States (MS) to ban the cultivation of genetically engineered (GE) plants in their respective territories for non-scientific reasons was adopted in March 2015. Under the transitional measures, the MS had until October 3, 2015 to request to be excluded from the geographical scope of the authorizations already 
granted or in the pipeline. Nineteen countries have decided to "opt out" of GE crops cultivation for all or part of their territories. T...

19 European countries restrict the cultivation of GE crops _Paris_EU-28_10-13-

2015

\section{Select EU Meat Production Hits Boundaries|Livestock and Products|The Hague|EU-28|9/14/2015}

In 2016, cattle herd levels are expected to grow marginally for the EU as a whole, but there will be a great deal of fluctuation within several EU Member States due to the abolishment of the EU milk quota this year. Elevated swine slaughter, mostly in Spain and Germany, will result in an excess supply of pork that cannot be absorbed by the current level of EU demand. As a result, the EU is forecast to export a record volume of pork in 2015 . The current negative market conditions are anticipate...

Livestock and Products Annual_The Hague_EU-28_9-9-

2015

Pork Markets Swimming in EU Pork|Livestock and Products Agricultural Situation Agriculture in the News|Brussels USEU|EU-28|9/9/2015

On September 7 an extra-ordinary Agricultural Council will be held in Brussels. It was called by the Luxembourg EU presidency in response to farmers' protests in various member states against low prices for mainly diary, pork and fruit and vegetables. Large numbers of farmers from various member states are expected to gather in Brussels, bringing tractors and cows in front of the EU institutions. This crisis results from the 2014 Russian ban on agricultural imports at a time that EU productio...

Pork Markets Swimming in EU Pork_Brussels USEU_EU-28_9-4-

2015

\section{A Perfect Storm for EU Dairy Prices|Dairy and Products Agricultural Situation|Brussels USEU|EU-28|8/20/2015}

Milk production margins in the European Union (EU) have turned negative in recent months as EU farmers continued to increase production following the end of the EU dairy quota system on April 1, 2015, while ignoring decreasing world dairy demand. The extension of the 2014 Russian embargo on agricultural imports has added additional downward pressure on dairy markets. This has led farmers in France to start protests, blocking roads, but also retail distribution centers and supermarkets. Belgi...

A Perfect Storm for EU Dairy Prices_Brussels USEU_EU-28_8-19-

2015

\section{Oilseeds Market Update|Oilseeds and Products Grain and Feed Biofuels|Vienna|EU-28|8/10/2015}

This report provides EU-28 production, supply, and demand forecasts for major EU oilseeds, protein meals and related products.

Oilseeds Market Update_Vienna_EU-28_8-5-

2015

\section{5|Biotechnology and Other New Production Technologies|Paris|EU-28|7/27/2015}

In the European Union, governments, the media, non-governmental organizations, consumers, and industry associations remain conflicted about the use of agricultural biotechnology. Acceptance varies widely across countries. A complex policy framework developed under pressure from anti-biotech activists has limited research, development, and production. The EU produces very few genetically engineered (GE) plants and animals but, with the growing adoption of biotechnology around the globe by lea...

Agricultural Biotechnology Annual_Paris_EU-28_7-23-2015

\section{EU Biofuels Annual 2015|Biofuels|The Hague|EU-28|7/22/2015}

On April 28, 2015, the European Parliament approved the reform of the RED, which includes a 7 percent cap on food crop based biofuels for the transport sector. The current blending of food crop based ethanol and biodiesel is estimated at respectively 3.3 and 4.3 percent. Further growth in the use of conventional biofuels will mainly depend on the successful introduction of the higher blends such as E10 and E85. But widespread use of these blends is hampered by the low fossil fuel prices and $i . .$.

Biofuels Annual_The Hague_EU-28_7-15-

2015

\section{Crop update - all eyes are on the weather|Grain and Feed|London|EU-28|7/22/2015}

The grain harvest is now under way in most Member States. Following an extended period of dry weather across much of 
the EU28 in the spring, which continued and worsened into the early summer in the west, attention is focusing on the size and quality of the wheat and barley crops as well as the development of the corn crop. With the weather over the coming weeks remaining a key influencing factor, the total MY2015/16 EU28 grain crop is revised to just over 305 MMT, down nearly 21 MMT on the re...

Crop update - all eyes are on the weather_London_EU-28_7-20-

2015

Biofuel Mandates in the EU by Member State|Biofuels Trade Policy Monitoring|Berlin|EU-28|7/16/2015

This report provides an overview on the biofuel use mandates in the various EU-28 member states. Biofuel Mandates in the EU by Member State_Berlin_EU-28_7-13-

2015

Dairy, Milk, Fluid, Dairy, Cheese, Dairy, Butter, Dairy, Milk, Nonfat Dry, Dairy, Dry Whole Milk Powder Semiannual|Dairy and Products|Warsaw|EU-28|5/20/2015

After a record jump of milk production in 2014, the increase of output is expected to decline in 2015 due to slower export demand, decrease of world market prices and high level of commercial stocks of dairy commodities. On March 31, 2015, European milk quota system was terminated. In expectation of price volatility the European Commission introduced in September 2014 and extended till September 2015 a temporary Private Storage Aid program for butter and Non Fat Dried Milk. Although the Russi...

Dairy and Products Semi-annual_Warsaw_EU-28_5-13-

2015

\section{Select 2015|Grain and Feed|London|EU-28|4/10/2015}

The outlook for the MY2015/16 EU28 grain crop is positive with another sizeable crop forecast, albeit down from the record volume achieved in MY2014/15. With the exception of some challenges in Romania and Bulgaria, winter crops benefitted from good planting conditions. A mild winter has seen crops develop well although recent conditions have been a little wet, notably in Hungary and its near neighbors. Spring planting is now under way, albeit subject to some weather-related delays in the sou...

Grain and Feed Annual_London_EU-28_3-27-

2015

Animal Numbers, Cattle, Meat, Beef and Veal, Animal Numbers, Swine, Meat, Swine EU meat sector withstands Russian ban|Livestock and Products|The Hague|EU-28|2/25/2015

Despite the Russian ban on pork and beef, the EU meat sector is forecast to retain production and export levels. The sector further improved its efficiency and benefitted from low feed prices. The competiveness of the sector is, however, combined with record low prices and tight or negative profit margins. Supported by the limited global supply of beef and pork, exports have been re-directed to alternative markets. Based on the favorable exchange rate of the Euro, EU exports of beef and pork...

Livestock and Products Semi-annual_The Hague_EU-28_3-16-

2015

Biotechnology and Other New Production Technologies|Biotechnology and Other New Production Technologies|Paris|EU-28|1/13/2015

In the European Union (EU), governments, the media, non-governmental organizations, consumers, and industry associations remain conflicted about the use of agricultural biotechnology. Acceptance varies widely across countries. A complex policy framework developed under pressure from anti-biotech activists has limited research, development, and production. The EU produces very few genetically engineered (GE) plants and animals but, with the growing adoption of biotechnology around the globe b...

Agricultural Biotechnology Annual_Paris_EU-28_1-9-2015 